CONSTRUCTING 'CANADIANS': A DISCOURSE ANALYSIS OF POLITICAL CONSTRUCTIONS IN THE DISCOVER CANADA CITIZENSHIP GUIDE

by

Sangeetha Nagendran, BA, University of Toronto, 2015

\author{
A Major Research Paper \\ presented to Ryerson University \\ in partial fulfillment of the requirements for the degree of \\ Master of Arts \\ in the Program of \\ Immigration and Settlement Studies
}

Toronto, Ontario, Canada, 2017

(C) Sangeetha Nagendran 2017 


\section{AUTHOR'S DECLARATION FOR ELECTRONIC SUBMISSION OF A MAJOR RESEARCH PAPER (MRP)}

I hereby declare that I am the sole author of this Major Research Paper. This is a true copy of the MRP, including any required final revisions.

I authorize Ryerson University to lend this MRP to other institutions or individuals for the purpose of scholarly research.

I further authorize Ryerson University to reproduce this MRP by photocopying or by other means, in total or in part, at the request of other institutions or individuals for the purpose of scholarly research.

I understand that my MRP may be made electronically available to the public.

Sangeetha Nagendran 


\title{
Constructing 'Canadians': A Discourse Analysis of Political Constructions in the Discover Canada Citizenship Guide
}

\author{
Sangeetha Nagendran \\ Master of Arts 2017 \\ Immigration and Settlement Studies \\ Ryerson University
}

\begin{abstract}
Under Stephen Harper's leadership, the Conservative government took active steps to maintain a particular Canadian identity. This notion is grounded in changes made to immigration policies and in Discover Canada, "where nation-specific definitions of citizenship" (Winter, 2014, p. 1) are outlined extensively. Discover Canada provides immigrants access to a specific construction of national history, while also highlighting Canada's pride in its multiculturalism. Thus, when considering Discover Canada as a representation of Canada's national identity, this MRP will interrogate the underlying discourses on which it is based by critically examining the guidebook. While the guidebook attempts to be inclusive-by including sections on 'Aboriginal Peoples' and 'Diversity in Canada' - it paradoxically provides a romanticized vision of history that fails to recognize persisting social inequalities resulting from a deeply rooted history of colonialism and systemic racism. This problematic portrayal of Canadian history, identity and multiculturalism may significantly disservice immigrants who seek meaningful inclusion and representation in Canada.
\end{abstract}

Key words: Political constructions and representations; national identity; citizenship; racialized immigrants and minorities; multiculturalism. 


\section{Acknowledgements}

I would like to thank my supervisor Dr. Tariq Amin-Khan and my second reader Dr. GraceEdward Galabuzi for their guidance and expertise. I would also like to thank my family and friends for their continued love and support during my time of study. Lastly, I would like to thank my passionate and dedicated cohort who have made this past year a memorable one. 


\section{TABLE OF CONTENTS}

Author's Declaration

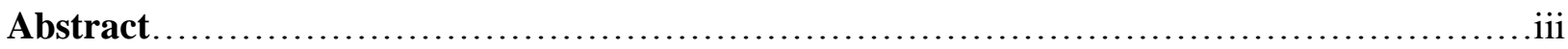

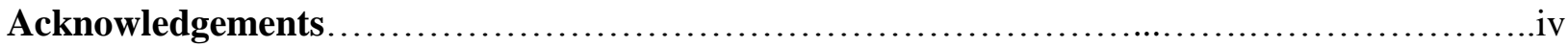

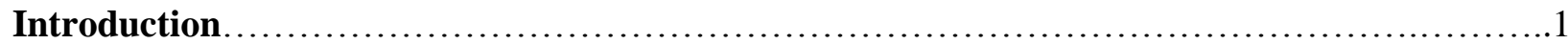

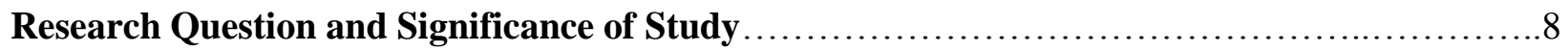

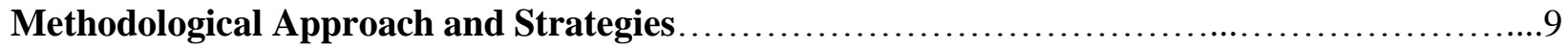

Theoretical Framework............................................................ 13

Literature Review: Exploring Multiculturalism in Relation to National Identity and History in

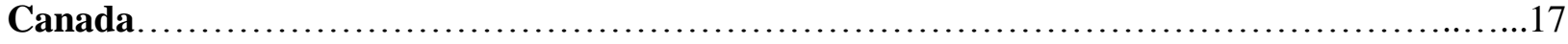

-The Emergence of 'Multiculturalism' in Canada.............................................. 17

-Conceptualizing 'Multiculturalism' in Canada..................................................20

-Multiculturalism's Impact on Canadian National Identity ....................................22

- The Rise of Xenophobia and Racism in Once Self-Identified Multicultural Nation States............24

-Is Discover Canada Rewriting Canadian History and Reorienting Multiculturalism?.................26

Chapter 1: Changes and Restrictions Made by Harper's Conservative Government Related to

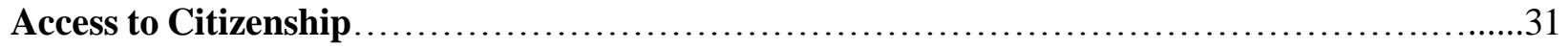

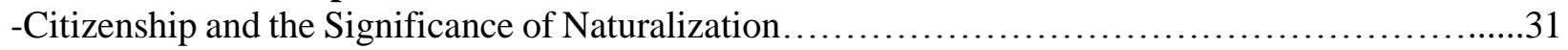

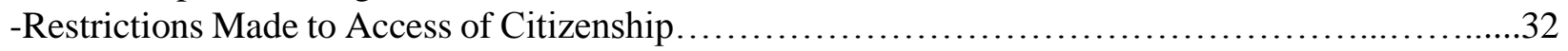

-Ramifications of Citizenship Changes for Newcomers...................................... 33

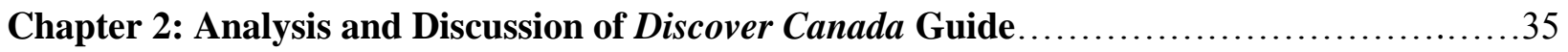

a) National History and Identity in Discover Canada ...........................................

-Political Revisions and Reductions of History........................................... 35

-Constructing Partisan National Mythologies............................................... 37

-Ramifications of Representation for Immigrants, Racialized Individuals and Other Minority

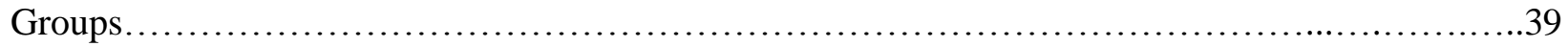

b) Racism-Infused Moral Panic in Discover Canada..........................................41

- Moral Panic and Racism Related to Immigrants' Cultural Practices............................41

- Imperial and Essentializing Modes of Thinking............................................. 46

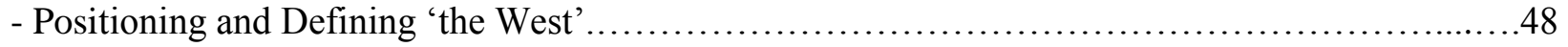

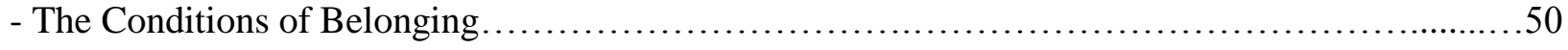

- Real-life Consequences Stemming from Discourse .........................................

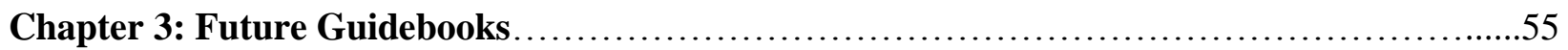

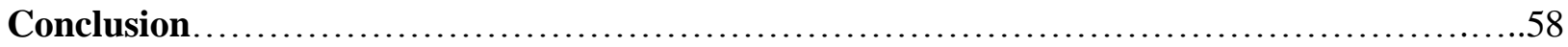

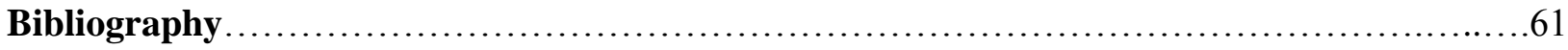




\section{Introduction}

In September 2009, during a G20 convention held in Pittsburgh, Pennsylvania, Stephen Harper stated the following:

We are one of the most stable regimes in history. There are very few countries that can say for nearly 150 years they've had the same political system without any social breakdown, political upheaval or invasion. We are unique in that regard. We also have no history of colonialism. (Wherry, 2009)

This statement comes roughly one year after Harper issued a statement of apology to former students of residential schools and to Aboriginal communities. Contrary to his remarks made at the G20 convention, Harper's apology acknowledges the Canadian government's role in implementing and regulating the oppression of Aboriginal communities which was "based on the assumption [that] Aboriginal cultures and spiritual beliefs were inferior and unequal" (Harper 2008). While Harper alludes to this historical oppression, he does not however explicitly mention how Canada's history of colonization led to the dispossession of land and marginalization of Aboriginal communities - which created the conditions that facilitated (what many refer to as) a 'cultural genocide'. Instead, Harper explains the impact Indian Residential Schools had on Aboriginal communities and the dehumanization of Indigenous people on which the policy was based. In his statement of apology, Harper stated:

The government now recognizes that the consequences of the Indian Residential Schools policy were profoundly negative and that this policy has had a lasting and damaging impact on Aboriginal culture, heritage and language...The legacy of Indian Residential Schools has contributed to social problems that continue to exist in many communities today. (Harper, 2008)

As some critics have suggested, this apology serves as an example of where highly "visible, short term gestures" (Brady, 2013, p.130) by the government are made in an attempt to promote "an idea of reconciliation" (p.130) while also "conceal[ing] the scars of colonisation" (Brady, 2013, p.130 as cited in Henderson and Wakeham, 2009). 
In light of this seemingly 'progressive' apology, it is very telling when one compares Harper's apology to his subsequent remarks at the G20 convention which explicitly deny Canada's history of colonization and the colonial foundations of many Canadian institutions. Harper has continuously contradicted and undermined (through his actions, policies and public expressions) many of the sentiments he once established in his apology that have significantly impacted the Aboriginal community. He thereby notably discredits the authenticity of his apology (Nagendran, 2015). For example, chief correspondent Peter Mansbridge asked Stephen Harper (in an interview with CBC News on Dec 17, 2014) about an inquiry into cases of missing and murdered Aboriginals in Canada. Mansbridge asked Harper if his government was at least "considering some form of formal inquest or inquiry or investigation" ("Peter Mansbridge's Interview," 2014). To this, Harper replies, “it isn't really high on our radar, to be honest...we have an awful lot of studies and information on the phenomenon and an awful good indication of what the record is in terms of investigation and prevention of these sorts of things" ("Peter Mansbridge's Interview," 2014). It is not at all surprising to learn that Stephen Harper does not have the lived experiences of Aboriginals "on [his] radar" ("Peter Mansbridge's Interview," 2014), despite making a public apology that seemed to suggest otherwise (Nagendran, 2015). This comment also does not seem all that surprising, especially considering that Harper and his Conservative government have exerted quite a bit of political effort throughout his leadership to maintain a particular Canadian identity — an identity which actually takes pride in its ties to colonialism (Abu-Laban, 2014).

In fact, many have criticized Harper's leadership as one characterized by anti-immigrant xenophobia, racist tendencies and one that has routinely engaged in the politics of fear. Harper's 
“"bullying' style" (Millard, 2009, p. 329) in the political arena has often included divisive rhetoric that engaged in processes where groups of people are made to be perceived as the 'Other'; this has not only been directed in relation to Aboriginal communities in Canada, but to other minority groups as well. In turn, Harper's role in the construction of specific minority groups as the Other has also simultaneously functioned to uphold notions of national identity and 'Canadian values'. As Gregory Millard writes:

[A] certain mentality embraces the robust demarcation and devaluing of an "outgroup," against whom the "in-group" is defined. In politics, this can manifest in many forms, but does so perhaps most classically in populism, which is predicated on the vigorous assertion of a spontaneously unified "people" against sundry out-groups. (Millard, 2009, p. 329).

As such, the oppressive act of devaluing the Other depends on how the Other or out-group is defined: "For instance: those forms of nationalist identity wherein the 'nation' and the 'state' are broadly understood to be coincident prima facie tend to define the out-group as some entity external to the state" (p. 229, emphasis in original). Similarly, Harper's Conservative government routinely engaged in the politics of fear and divisive rhetoric — especially during his election campaigns - which characteristically constructed 'Others' as external to and a threat to the nation-state. However, attitudes towards 'external' out-groups or Others also extend to groups who are already within the nation state, and sometimes even its own citizens (Millard, 2009).

In Canada for instance, this mechanism of constructing the Other—often employed by political leaders and Canadian media outlets - allows for the in-group to turn against its fellow Muslim citizens in the face of terrorism and amidst increased state securitization and regulation. It is also this same mechanism that allows the in-group to perceive that immigrants bring 'cultural baggage' with them to Canada, which threaten 'Canadian Values' (Millard, 2009). 
Again, it is these same mechanisms that also allow for issues faced by Aboriginals in Canada to be treated and viewed as separate from issues that affect other Canadian citizens. Millard writes that "when we marginalize citizens of our own polity, we subject them to power in a way seldom true for external out-groups" (p. 330, emphasis in original). However, while this statement may be true to a certain extent, it falls short when considering Harper's stance on issues related to immigration. Thus, the processes of constructing the Other by political leaders-which often influence public opinion and policy making — do affect and can marginalize those within our borders, but can also significantly affect those who are beyond them; this can lead to very real consequences for those individuals (especially in relation to their migration choices and processes).

However, Harper does not represent an isolated case where the politics of fear has given way to increasingly restrictive stances on immigration policy and minority rights. In fact, Harper represents a symptom of a larger global trend towards extreme political right attitudes characterized by neoliberalism, conservatism, xenophobia, islamophobia, and racism. The 9/11 terrorists' attacks against the United States marks a flashpoint where radical right attitudes in the West were magnified and proliferated. Following the attacks, US President Bush stated, "You are either with us or against us in the fight against terrorism" (Gündüz, 2010, p.36). Bush also referred to a "crusade" against (Islamist) terrorism" and made claims that "they [Muslims] hate our freedoms" (Gündüz, 2010, p.36). The events of the 9/11 attacks coupled with this political rhetoric sparked existing hostility towards the 'foreign Other' in the West. Muslims and individuals wrongly assumed to be Muslim were looked upon "with mistrust and skepticism and who more often than not were accused of helping the terrorists or even being terrorists themselves" (Gündüz, 2010, p.36). Similar events of terrorism in Europe bolstered already 
existing hostilities towards the foreign Other as well. These attitudes and fears towards the Other, which often position foreigners as a threat to the very fabric of a nation, led to the rise and popularity of far-right political leaders across Europe and the West, including Stephen Harper here in Canada. During an era where the movement of people across national borders continuously increases for a myriad of reasons, there is a paralleling rise of immigrant hysteria from receiving countries as well. World powers such as countries in Europe, the United States, Australia, and Canada determine and dictate the global narratives on migration and immigration. As such, these narratives coupled with right-wing political agendas often support increased securitization and legitimizes increasingly restrictive immigration policies, such as making it more difficult for immigrants to obtain legal citizenship.

Similarly, under Stephen Harper's Conservative leadership, significant changes were made to immigration and integration policies making it increasingly more difficult for newcomers to obtain citizenship in Canada ("Barriers to Citizenship," 2014). Changes made include applications for citizenship being costlier, new additional language requirements, and citizenship exams which were made more difficult. These increased restrictions do a great disservice to immigrants who seek meaningful inclusion and active participation in society. Moreover, these changes have "a disproportionate impact on more vulnerable newcomers, such as refugees and more isolated or low-income newcomers" (Barriers to Citizenship," 2014). For many newcomers, access to rights and citizenship also have meaningful ties to identity. However, Harper's Conservative government took many active steps to maintain a particular Canadian identity. In shaping this Canadian identity, the Harper government had a direct hand in the exclusion of minority groups from a sense of belonging in Canada, as well as in constructing the 'ideal' or 'good' Canadian citizen. This notion is grounded in changes made 
to immigration policies and changes made to Canada's Citizenship and Immigration study guide, Discover Canada (a guidebook that was introduced under Harper's government in 2009), which focuses heavily on Canadian militarism, our colonial connection to Britain and it is also "where nation-specific definitions of citizenship" (Winter, 2014, p. 1) are outlined extensively. These changes made to the naturalization process and the study guide reflect Canadian neoliberalism, conservatism, and a more restrictive immigration policy that ultimately functions to exclude specific groups of people from Canada's national identity and from full and active participation in society.

With this in mind, it is important to understand how the Canadian government conceives of citizenship and how it may have meaningful ties to identity and immigrants' social inclusion within the context of a nation which claims to be multicultural; this claim that Canada is a multicultural society is often reinforced by political bodies and actors. Multiculturalism in Canada as an ideology, a demographic fact, and as policy (Berry, 2017) has been studied extensively by academics. However, with the introduction of a new citizenship study guide (which is underway by the current Liberal government), it is worthwhile to extend this area of study to explore the government's role in creating or reinscribing specific representations of multiculturalism in Canada, in relation to government produced conceptions of Canadian history, values, and identity. This notion can be examined in Discover Canada: The Rights and Responsibilities of Citizenship, which is a document produced by Citizenship and Immigration Canada to be "used by newcomers to study for the citizenship test" (Government of Canada, 2015).

Furthermore, Discover Canada is a snapshot of Canada's national narrative and identity from the perspective of the Canadian government (more specifically, Stephen Harper's 
Conservative government). It provides new immigrants with a point of access to a specific construction of national history, while also highlighting Canada's pride in its diversity and multiculturalism. Thus, when considering the study guide as a representation of Canada's national identity, we must interrogate the underlying discourses on which it is based. The national identity that is constructed in this guide focuses heavily on Canadian militarism and Canada's colonial connection to Britain. While the guide attempts to be inclusive-by including sections on 'Aboriginal Peoples' and 'Diversity in Canada' - it falls short and paradoxically provides a romanticized vision of history that fails to recognize persisting social inequalities that result from a deeply rooted colonial history and systemic racism. This problematic portrayal of Canadian history, identity and multiculturalism may significantly disservice immigrants who seek meaningful inclusion and representation in Canadian society. While preparations for a new guidebook by the Liberal government are currently underway, it is still worthwhile to assess how political constructions and representations of Canada can shed light on the Harper government's ideological underpinnings which have impacted policy changes, as well as issues relating to white nationalism and identity in Canada that persist today. 


\section{Research Question and Significance of Study}

Therefore, to further understand some of the concerns raised thus far, examining Discover Canada will help illuminate how Canadian multiculturalism has changed and evolved over time. It will also be a point of reference to further understand political constructions and representations of meaning. Thus, the following research question will guide this Major Research Paper (MRP): How is Canadian history and identity constructed within the Discover Canada study guide and what are the implications of this construction on racialized "newcomers" and the ideology of Canadian multiculturalism? Ultimately, this question aims to explore how immigrants are positioned in relation to these constructions and representations.

The goal of this MRP is to problematize the ideology of multiculturalism in Canada and to potentially illuminate both the shortcomings and merits of this study guide. In doing so, I aim to also make recommendations for future changes to new government produced citizenship study guides. This MRP will also build upon the theoretical work of scholars who have studied multiculturalism's ties to national identity and history. It is important to problematize the ideology of multiculturalism, as it is becoming an increasingly deeply-embedded notion in Canadian society that is used routinely in political rhetoric. However, as other scholars have suggested, upholding and promoting the ideology of multiculturalism alone does not ensure a sense of belonging, inclusion, and membership for many immigrants. By highlighting problematic representations in Discover Canada, I hope to facilitate a broader discussion and understanding of the implications of these government produced representations of Canada in the guide. 


\section{Methodological Approach and Strategies}

For this MRP, I will be using the methodology of discourse analysis to analyze the Discover Canada guide. Foucault understands discourses as productive (Kendall and Wickham, 1999); in other words, discourses are socially produced, where meaning or knowledges are constructed by social actors. Therefore, discourses or frameworks of meaning "are not regarded as 'discoveries' by humans of the true nature of the world, rather they have been 'fabricated' (in the engineering sense)" (White, 2004, p. 9). With this understanding of discourse, if meaning can be constructed, it can also be deconstructed. As such, “'discourse analysis' as a research method examines human speech/writing, actions and products (texts) to identify and analyze these 'ways of understanding"” (p. 9). According to Hardy et al., discourse analysis is a qualitative, interpretive and constructionist methodology that can be used to analyze social phenomena. They also assert that it explores "how the socially produced ideas and objects that populate the world were created and are held in place" (Hardy et al., 2004, p. 19). There is no agreed upon consensus of what discourse analysis entails; however, the term 'discourse' itself is a broad term and its definition is often contested and described in varying ways by scholars. Laffey and Weldes describe discourse as the practices and structures that are used to construct meaning. Crawford similarly asserts that discourse is "the content and construction of meaning and the organization of knowledge in a particular realm" (Herrera and Braumoeller, 2004, p. 16 as cited in Crawford, 2004). Discourse analysis brings together both epistemology and ontology by asking "how we came to know the representation (words, phrases, language, gestures, etc.) that we claim constitute reality" (Herrera and Braumoeller, 2004, p. 16).

Thus, context cannot be divorced from discourse analysis - rather, context is quite central to discourse analysis. Further, this constructionist approach of discourse analysis (which 
"assumes that reality is socially constructed") is the rationale behind using this methodology, rather than choosing to do content analysis of the guide book (which takes a realist approach and "assumes that an independent reality exists") (Hardy et al., 2004, p. 21). In other words, discourses do not have inherent meaning in themselves and therefore efforts must be made to understand their constructive effects by locating them historically and socially (Hardy et. al, 2004). For this MRP, an integral aspect of analysis will be interrogating the power relations that exist when government and political actors engage in the 'politics of representation.' A fundamental concern of discourse analysis is analyzing the "way in which power relations structure, constrain, and produce systems of meaning” (Herrera and Braumoeller, 2004, p. 19). Thus, using discourse analysis as a methodology will help better illuminate constructions of meaning when some features in the guidebook are deliberately chosen by powerful political elites to be represented, while other representations are purposefully omitted.

Moreover, in approaching this project from an anti-colonial and anti-racist perspective, I must also situate these theoretical frameworks within a particular context. As, Hardy et al. write: "The meanings of any discourse are 'created, supported, and contested through the production, dissemination, and consumption of texts; and emanate from interactions between the social groups and the complex societal structures in which the discourse is embedded"' (Hardy et al., 2004, p.20 as cited in Hardy, 2001, p. 28). While discourse analysis is based on social constructivist epistemology, it also stems from the belief that meaning and ultimately social reality emerges from "interrelated bodies of texts - called discourses - that bring new ideas, objects and practices into the world...[and] into being" (Hardy et al., 2004, p. 20). Similarly, an anti-colonial and anti-racist lens takes a constructionist approach, and these epistemologies (situated within the context of this study) appear to go hand-in-hand. 
While multicultural rhetoric emerges in Canadian society in many different areas (such as in the media, in education related policies, and in workplace settings for instance) the scope of this MRP will focus solely on multicultural discourse related to the Canadian government, the study guide itself and it will occasionally draw from news sources that specifically report on political and government actions or events. While the scope of this project is limited to these parameters, "[t]he need to link text, context and discourse, and to incorporate a highly subjective and reflexive use of research methods, poses a major challenge for researchers" (Phillips and Hardy, 2002, p. 10). As it is impossible to study all aspects of discourse, to make research manageable, these parameters are established beforehand.

Therefore, this project began with gathering relevant information and sources needed to conduct this research. The information used for analysis was largely obtained from the Discover Canada study guide itself. In addition to this, I refer to newspaper articles that cover political actors' involvement in changes to citizenship processes, changes to the guide, or those that report on political actors' speeches/rhetoric that directly relate with notions of 'Canadian values,' Canadian identity and multiculturalism in relation to citizenship. Also, scholarly literature informs my work and provides contextual information. I have also examined gray literature, newspaper articles and academic work to learn more about the production, release and distribution of the Discover Canada guide. This is to assess the extent of the government's role in producing the guidebook and what content it contained. My initial few examinations of the study guide involved taking note of the layout of the guide (considering page numbers, number of sections, section titles, cover pages, images, etc.).

Next, the Discover Canada guide was reviewed extensively and coded. Based on the literature review, I established a few preliminary codes. I engaged in a process of open coding 
and then shifted into axial coding, taking one core category that has emerged in open coding and linking it to all the subcategories that connect with the core category (Ali, 2017). After multiple readings and once most codes had been identified, the codes were categorized. After coding was completed and organized in broader categories, connections among codes were identified, hierarchies among codes were developed, and themes were identified and organized based on relevance to my research question. Informed by my theoretical foundations (post-colonial theory and an anti-racist perspective), these themes will then be analyzed and the meanings will be contextualized. Through this contextualization and analysis of information, I will attempt to answer my research question. 


\section{Theoretical Framework}

Since this paper focuses upon the political constructions and representations of 'Canada' (as a social and cultural form of national identity), a post-colonial lens with an anti-racist perspective will be the mode of analysis which attempts to challenge or interrupt these constructions (Bannerji, 2008). Simply put, "[p]ost-colonial theory is a term for a collection of theoretical and critical strategies used to examine culture (literature, politics history, and so forth) of former colonies of the European empires, and their relation to the rest of the world" (Makaryk, 1993, p.155). While there is no single method or approach to post-colonial theory, this perspective often includes examining racism, racial oppression, or exploitation (often within the state). Furthermore, post-colonialism often brings the colonial or post-colonial subject to the forefront of examination (Makaryk, 1993).

While it is difficult to determine who first developed or coined the theory, there are several important figures whose work have been influential in this school of thought. For instance, Frantz Fanon in Black Skin, White Masks, as well as The Wretched of the Earth, shines the spotlight on the colonial subject as the Other and highlights the inability of that colonial subject to be positioned as 'Self' within post-colonial states (Makaryk, 1993). This binary between Self and Other has been a point of discussion in many post-colonial debates and finds its way in this MRP as well. Moreover, Edward Said's Orientalism published in 1978, which focused upon European constructed representations of the Middle East and how orientalism functions, also became an influential text in post-colonial studies. When considering key influential theorists of post-colonial studies, it would be remiss to not also make mention of Gayatri Chakravorty Spivak and Homi K. Bhabha. However, the difficulty in naming influential figures in this school of thought or attempting to define this theory comprehensively is that this 
process is problematic altogether. When considering post-colonial theory, or rather theories, it is important to understand that each nation and region has its own post-colonial critical traditions and key players (Makaryk, 1993). Post-colonial theory has been extended and expanded over the years to examine multiple power relations between the colonial or post-colonial subject and the state; as such, these examinations are often context dependent.

For instance, when considering Canada as the point of study, it becomes clear that Canada as a former colonial state drastically differs from previously colonized states, such as India for example. Canada is a settler colony which was first colonized by the French and then subsequently by the English. Moreover, the diversity, or 'multiculturalism' of Canada's population today “complicate[s] the relation between indigenous and settler countries' (Makaryk, 1993, p. 156). Thus, the unique histories of each region must be considered and how postcoloniality is understood in each of these contexts must be clarified at the onset of study.

Therefore, in order to understand political constructions of 'Canada' in the Discover Canada citizenship study guide and by extension Canadian identity in this paper, Canada's unique history of colonialism must be brought to the forefront of discussion. As Himani Bannerji writes, in order to get a better understanding of the relationship between the state and those who are seen as Other, "colonialism is the context or entry point that allows us to begin exploring the social relations and cultural forms which characterize these relations" (Bannerji, 2008, p. 107). Although Himani Banerji, strictly speaking, is not a postcolonial theorist, her insight on the impact of colonialism on post-colonial societies is valuable. For instance, Bannerji asserts that the category of 'visible minority' in Canada is produced by the multiculturalist policy of the state (Bannerji, 2008). In other words, the category of visible minority exists as a direct result of multiculturalism, and in turn, multiculturalism depends on the existence and maintenance of such 
categories. As Craig Calhoun similarly asserts, nationalism and ethnicity "are part of a modern set of categorical identities invoked by elites and other participants in political and social struggles. The categorical identities also shape everyday life, offering both tools for grasping pre-existing homogeneity and difference and for constructing specific versions of such identities" (Calhoun, 1993, p. 211). Thus, exploring the construction of visible minorities in Canada as part of the 'social imaginary' for example, must be understood in relation to Canada's specific context of colonialism (such as its conquests, war, and exclusionary policies) that have allowed for such constructions to take root (Bannerji, 2008).

Therefore, using post-colonial theory with an anti-racist approach aims to interrupt these constructions and by extension also disrupts the social imaginary that maintains these constructions. The maintenance of a social imaginary, similar to Benedict's Anderson's concept of an 'imagined community,' is often dependent on unified and fixed understandings of social belonging (Anderson, 1983). However, with Canada's historical foundation of colonization, Eurocentrism and racism in relation to Canada's current diverse demographics, notions of unity are perpetually in crisis (Bannerji, 2008). As Bannerji writes:

[W] consequently have a situation where no escape is possible from divisive social relations. The nation state's need for an ideology that can avert a complete rupture becomes desperate, and gives rise to a multicultural ideology which both needs and creates 'others' while subverting demands for anti-racism and political equality. (p. 110).

Maintaining a sense of nationalism is integral for the state and for maintaining its hegemonic power; thus, even within a context like Canada—where multiculturalism is seemingly promoted and needed — nationalist rhetoric can still function simultaneously to "demarcate political communities, claim rights to self-determination and legitimate rule by reference to 'the people' of a country" (Calhoun, 1993, p.211). Even within a self-identified multicultural state like 
Canada, there is still an attempt by political figures to address the country as a unified, homogenous collective.

However, Bryan D. Palmer points out that "One problem with the overworked use of Benedict Anderson's phrase 'imagined community' is that those who employ it sometimes fail to acknowledge adequately that all nations are fractured into different and often contesting components. 'Community,' in any meaningful sense, is never realizable within nations, ordered as they currently are, fragmented by powerful divisions" (Palmer, 2014, p.234). In the context of a multicultural state like Canada, Palmer's assertions are supported here, especially when considering Indigenous groups, racialized groups and other marginalized or minority groups. Therefore, approaching this discussion with an anti-racist perspective is also necessary if one aims to understand the relationship between the state and those who are routinely (through political rhetoric or otherwise) seen as outsiders, despite residing within a nation that deems itself multicultural. 


\section{Literature Review: Exploring Multiculturalism in Relation to National Identity and History in Canada}

This literature review will begin by outlining the historical emergence of 'multiculturalism' in Canada and it will then shift into the different ways in which multiculturalism is conceptualized. Furthermore, multiculturalism's impacts on Canadian national identity and constructions of national history will be outlined. Also, a discussion of the rise of xenophobia and racism in multicultural states will be briefly explored for the purpose of contextualizing and grounding this paper. This section will then be followed by various scholars' critiques of multiculturalism, national identity, and constructions of national history which are situated within the context of the Discover Canada study guide, which will then lead into my own analysis and critical discussion of the guidebook.

\section{The Emergence of 'Multiculturalism' in Canada}

The emergence of multiculturalism in Canada did not result from a simple linear line of events. There were purposeful and active strides taken by government officials to promote the ideology of multiculturalism in Canada, which have had long lasting implications that continue to endure today. For example, amidst growing separatism in Quebec, Prime Minister Lester B. Pearson (1963-68) believed that the best way to handle the growing divide was to "accommodate Quebec's demands" (Guibernau, 2007, p. 34). In turn, the Royal Commission on Bilingualism and Biculturalism was established. This would allow the Commission to "recommend what steps should be taken to develop the Canadian Confederation on the basis of an equal partnership between the two founding races, taking into account the contributions made by the other ethnic groups to the cultural enrichment of Canada and the measures that should be taken to safeguard that contribution" (p. 34). Pearson took many other active steps to accommodate Quebec, which allowed the province to engage in its own nation-building project. For many Quebeckers, these 
accommodations also included the idea that French people were recognized as one of the two founding peoples of Canada (Guibernau, 2007).

However, Pearson's successor, Prime Minister Elliot Trudeau (1968-79 and 1980-84) did not share Pearson's accommodating sensibilities. Instead, Trudeau "despised nationalism and was determined to eradicate it by incorporating Quebec Francophones into a new pan-Canadian identity. Trudeau... regarded Quebec as a backward society and defined its nationalism as the enemy of democracy, individual rights and social and economic justice.” (p. 35). In an effort to weaken Quebec nationalism, Trudeau ironically laid the groundwork for a new kind of Canadian nationalism; this notion of pan-Canadian identity was consequently supported by many AngloCanadians. Moreover, promoting bilingualism was a hallmark of Trudeau's nation building project. His underlying motive for promoting bilingualism in Canada was to prompt French Canadians and English Canadians to better understand each other and to consequently unite together. This in turn, Trudeau believed, would undercut Quebec's nationalism (Guibernau, 2007).

Furthermore, in 1971, Trudeau had stated that "there are no official cultures in Canada" (p. 37). The Trudeau government continued to promote ideas related to multiculturalism, parallel to notions of bilingualism, and these ideas were adopted as official policy in the Multiculturalism Act of 1988 (Berry, 2017). The Director of Multiculturalism at the time, asserted that multiculturalism would not only exist as a social fact, but also as public policy and in programs. More than being a cultural policy, it also served as an equity policy created "to preserve and enhance the multicultural heritage of Canadians... working to achieve the equality of all Canadians in the economic, cultural, social and political life of Canada" (p. 644). More recently however, there are growing concerns about the low socio-economic position of particular 
groups - such as Aboriginal Peoples, immigrants and other racialized groups - who despite living in a space that claims to be multicultural and inclusive, still continue to face institutional and structural barriers that function to marginalize these individuals. In light of this concern, it becomes clear that multicultural policy (adopted since 1988) does not necessarily ensure or translate to equitable social positioning in a plural society (Berry, 2017).

With multicultural policy shifting "from the preservation of cultures to the promotion of equality" (Guibernau, 2007, p. 37), Guibernau outlines that multiculturalism had mixed impacts on national unity. She states that the divide between Anglophones and Francophones widened. It also consequently "robbed Canadian identity of any real core...[making it] difficult to designate any set of values that are common to all Canadians" (p. 38). While many critics argue that multiculturalism is a significant factor in constructing a Canadian national identity, others in different cultural and national contexts often view multiculturalism as something that undermines 'national' values and identity altogether. For instance, German Chancellor Merkel in 2010, stated that "multiculturalism has 'utterly failed' because it allegedly nurtured the emergence of "parallel societies"” (Winter, 2017, p. 639). Views that are similar to the German Chancellor's convictions can only be maintained if one considers who or which segments of the population are intended to be served by multiculturalism. From Merkel's view, concerns about immigrants' social integration arise and these 'parallel societies' of immigrants are seen as threatening to national values and identity. Multiculturalism here, is deemed a failure when more powerful political groups serving white interests are left to dictate the parameters for successful integration (within the context of multicultural societies). Thus, if social integration, or rather assimilation is favoured by a society, multiculturalism is consequently viewed as a threat to the dominant Eurocentric way of life, as it is perceived to undermine social homogeneity. 


\section{Conceptualizing 'Multiculturalism' in Canada}

J.W. Berry writes that in the past 40 years, the term multiculturalism has been conceptualized in three distinct ways. First, multiculturalism is conceptualized as a "demographic fact (the presence of cultural diversity in the Canadian population)" (Berry, 2017, p. 664). Second, multiculturalism also has an ideological meaning where there is a "general desirability among Canadians for maintaining and sharing this diversity” (p. 644). Lastly, multiculturalism can also be differentiated in terms of public policy of "governmental orientation and action towards this fact" (p. 644). All three of these conceptualizations are intrinsically linked. It is important to understand how multiculturalism functions differently on these three levels, but also how they work together to influence each other. Furthermore, as Berry writes, "At the psychological core of the meaning of multiculturalism lies the notion of individuals having and sharing a collective identity as Canadians, and who also have particular identities as members of various ethnocultural communities" (p. 644). Thus, it is difficult to discuss multiculturalism in Canada without discussing national identity in the process as they are significantly interconnected.

Often times however, in both national and international debates, multiculturalism has been problematically equated with cultural diversity. Berry asserts that Canadian policy not only encompasses the "recognition, promotion and celebration of cultural diversity" (p. 665) but also includes "intercultural sharing, equity and inclusion" (p. 665). Often, critics of multiculturalism who conflate the term with just simply cultural diversity often view it narrowly as creating social divisions and separations (Berry, 2017). Thus, as Berry points out, multiculturalism policy in Canada features both diversity and equity in its conception. However, these two facets have not been emphasized or promoted equally over the past 40 years: 
At the beginning, there was a focus on support for the maintenance of cultural diversity; this appears to have been an effort to halt (or reduce) the assimilationist features of earlier policies. Later, the other core concern in the policy (for sharing, equity and social inclusion) came to be emphasised more. And most recently the incorporation of everyone into a Canadian civic society has come to the fore with an emphasis on a common citizenship for all. (p. 665)

To this I add, that multicultural policy seems to not only be a promotion of more equitable practices and ideas in Canada, but also functions as a management tool or strategy to deal with, or rather assimilate Canada's increasing culturally diverse demographics.

Moreover, Roger Hewitt writes that in Canada, multiculturalism has often been treated as separate from issues pertaining to racism. In Canada, as well as Australia, multiculturalism emerges from a similar historical immigration backdrop where a 'whites only' immigration policy was previously maintained (Hewitt, 2005). For instance, the presence of a Chinese immigrant population in Canada in the late nineteenth century became a national focal point. Between 1885 and 1923, numerous laws were implemented that legally prohibited Chinese migrants from entry into Canada and excluded Chinese immigrants from formal citizenship (Hewitt, 2005). These laws attempted to prevent Chinese settlement in Canada and "became the basis for a de facto 'whites only policy' that lasted well into the post-World War II period" (p. 133, emphasis in original). Settlement in Canada remained predominantly British or French; however, white non-Anglophone and non-Francophone northern, eastern and southern Europeans also became major settler communities (Hewitt, 2005).

Yet, Hewitt asserts that what motivated the development of political concern related to settlement and cultural recognition in Canada was not a result of interests belonging to First Nations and other non-white groups. Rather, it was related to issues of the Francophone community regarding their language rights, as well as the Quebecois separatist movement that became the driving force behind cultural recognition in Canada (Hewitt, 2005). Hewitt writes 
that "although measures to address the specific interests of the visible minorities were gradually introduced, these matters have been generally treated as separate from the 'mosaic' vision of Canadian diversity" (p.133). While efforts have been made to expand cultural recognition to include Indigenous issues and issues related to racialized immigrants for example, there is still a significant amount of progress to be made.

\section{Multiculturalism's Impact on Canadian National Identity}

For instance, from an anti-racist or post-colonial perspective, approaches towards multiculturalism have often been viewed as serving White supremacy and nationalism. As such, these critics assert that supposed concerns over 'multicultural recognition' and 'minority rights' "camouflage a politics of containment practiced by the dominant group" (Winter, 2015, p. 639). Thus, cultures belonging to Aboriginal groups, French Canadians and immigrants are framed as marginal in relation to the dominant culture of Anglo-Saxons. Canadian Anglo-Saxons within this framework are unmarked, 'de-ethnicized' and consequently normative, while others in relation to this norm are constructed as 'multicultural' or 'ethnic' (Winter, 2015).

Similarly, Elke Winter asserts that the symbolic idea of Canadian multiculturalism as a mosaic in relation to the United States' melting pot allows White or Anglo-Saxons to develop a distinct national identity; this identity allows them to "take pride in a presumably more tolerant and 'caring' approach to minorities" (p. 640). In discussions about multiculturalism, visible minorities, immigrants and Aboriginal communities are often positioned or framed as the 'ethnic Other' who need to be 'tolerated' by the larger Canadian society. Despite policy makers intending to promote equity through multicultural policy, its subsequent impact on identity functions to create further divisions between minority groups and dominant social groups (Anglo-Saxons and French Canadians). 
Furthermore, in response to Elke Winter's work, Us, Them and Others: Pluralism and National Identity in Diverse Societies, Catherine Frost writes:

[T] hose who view multiculturalism as a progressive concession to difference and those who critique it as a sinister form of social containment, have both got it wrong. Canadian multiculturalism is neither given, nor imposed. It is negotiated among multiple motivated parties, all with something to gain. And what gets negotiated is a kind of "conditional inclusion" for diversity that characterizes Canadian pluralism. This is how the national identity becomes pluralist. In effect, it could never be anything else. (Frost, 2011, p. 255)

Therefore, the construction of multiculturalism is a highly political process with real stakes and it is important to interrogate who 'gains' what from upholding such ideologies.

For both Winter and Frost, multiculturalism and its resilience in Canadian society is due to what has now become an intrinsic tie to national identity. At the same time, multiculturalism is also a result of a "negotiated compromise" (Frost, 2011, p. 255) that is constantly in motion and changing. Frost "suggest[s] that this new account requires one to view Canada as a savvy manipulator of multiculturalism rather than its greatest champion" (p. 262). According to Winter, traditional nation-building projects often align with concerns of unifying or homogenizing a nation, similar to Anderson's vision of an "imagined community" (Frost, 2011, p. 262). However, when it comes to Canada, the nation-building project does not follow these traditional models. Instead, nation-building in Canada occurs in a context where "homogeneity is not an option" (p. 262). From this, Frost asserts that traditional modes of nation-building are too restrictive, narrow, and inflexible in the Canadian context. However, Canada's nation building project is "characterized by persistence, creativity, and adaptation" (p. 262). The adaptive nature of multiculturalism in Canada, and its close relationship to nation-building projects has allowed this ideology to persist in Canadian society; thus, it is significantly important to understand multiculturalism as it exists (as a demographic fact, as ideology and as policy) to understand who 
or which groups it serves and to what extent (and conversely, who multiculturalism disservices as well).

\section{The Rise of Xenophobia and Racism in Once Self-Identified Multicultural Nation States}

However, looking beyond Canada, nations that once seemingly embraced

multiculturalism often also harboured and bolstered xenophobic and racist attitudes; ultimately, many nations have distanced themselves from multiculturalism and multicultural policies altogether. In the case of Europe, ethnic and religious qualities belonging to immigrant outsiders pose a perceived challenge to "the collective identities of Europe's core groups," and "struggles over multicultural incorporation have centred on immigration, particularly from Islamic regions" (Alexander, 2013, p. 533). Jeffrey C. Alexander asserts that the European Union (EU) represents a "radical experiment in supra-national and anti-ethnic democracy" which is also experiencing a sense of endangerment and vulnerability, especially from increased global migration (p. 533). This perceived threat to the EU has led to increasingly restrictive legal, administrative and political measures, the rise in popularity of extremist political parties, and a growing number of cases of violence against Muslims (some attacks being orchestrated to harm "outspoken supporters of the multicultural expansion of European civil societies") (p.533). Backlash against immigration and multiculturalism, as well as xenophobic attitudes are being harboured across many European countries.

Furthermore, the 'war on terror' that has gripped nations across Europe has significantly impacted and continues to affect race relations policies. Increased securitization-which involves new legislation, increased policing, and new counter-terrorist measures-positions Muslims within the state as the 'enemy within' (Fekete, 2004). This trend of rising xenophobia and racism is not only directed towards asylum seekers, but unfortunately extends to Muslim 
communities as well. The events of 9/11, in addition to other terror attacks in Europe have created unprecedented fears toward Islam itself, which is often viewed as a threat to Europe. Consequently, European nations are responding with what Liz Fekete describes as "draconian attacks on civil rights... with moves to roll back multiculturalism and promote monocultural homogeneity through assimilation" (Fekete, 2004, p. 3).

Thus, nations like France, which now favours state secularism, began discussing socalled 'integration' measures — such as banning the hijab — that paralleled changing anti-terrorist laws. This political climate has led way to rampant Islamophobia and "structured anti-Muslim racism" (p.3). Moreover, in the Netherlands, an assimilationist model that focuses upon the themes of 'standards and values' has similarly taken root. In Sweden and Norway, discussions about cultural barriers to inclusion are rampant. Likewise, the UK is occupied with 'community cohesion,' Germany is focused on 'Leitkultur' (leading culture), and Denmark is focused on immigrants' 'intolerant culture' that prevents integration. While these different terms all profess to promote the objective of integration, they are all coded words for an assimilationist approach in dealing with immigrant or racialized communities where perceived difference and multicultural policy pose a threat to "core values, cultural homogeneity and social cohesion" (Fekete, 2004. P.18).

In the case of Australia, multicultural policies were introduced in the early 1970s "to address at the level of state planning the increasingly apparent failure of the unrealistic policies of assimilation which they replaced" (Poynting and Mason, 2008, p. 231). However, in a similar way to the US, Europe and Canada, the 'War on Terror' since 9/11 has also seen a marked shift in the Australian government's response to growing racial and ethnic diversity in the country. For instance, as Poynting and Mason describe, Australia has "increasingly seen the intrusion of 
the state into cultural, and especially religious, matters of minority populations, overwhelmingly among Muslims” (p. 230). 'Australian values' are routinely upheld and political leaders even dictate what they see is acceptable in a sermon, and conversely what is unacceptable, extreme, or radical. The Australian government has also gone as far as demanding that ethnic and religious schools teach 'Australian values.' (Poynting and Mason, 2008). While there is no legal basis for this demand, it does illustrate a deep-rooted fear of the 'foreign Other' as a threat to widespread national understandings of 'Australian values' and it represents a backlash against multiculturalism's accommodation of cultural diversity.

Thus, as global migration has increased, nations that once openly embraced multiculturalism have began turning away from it, and instead have shifted towards increased securitization. Also, neoliberalism coupled with increased xenophobia and racism, has created an environment that fosters hostility and fear towards Muslims and those who are simply perceived to be Muslim. Despite similar xenophobic attitudes also present in Canada, Canada remains the only self-identified multicultural state currently in the Western world. Thus, Canada serves as a unique point of study in understanding the complex relationship where rising xenophobic sentiment and the ideology of multiculturalism can be seen embedded in political rhetoric at the same time.

\section{Is Discover Canada Rewriting Canadian History and Reorienting Multiculturalism?}

In Canada, former Prime Minister Stephen Harper and his Conservative government exerted a substantial amount of effort in maintaining an exclusionary Canadian identity. In April 2009, the Minister for Immigration and Multiculturalism, Jason Kenney, announced that there would be significant changes made to the national citizenship program which included revising the existing study guide, A Look at Canada. He promised the result would entail a "renewed 
emphasis on 'Canadian values"' (Chapnick, 2011, p. 20). Discover Canada: The Rights and Responsibilities of Citizenship was introduced by the federal government six months after this announcement. Compared to the A Look at Canada study guide, Discover Canada is about fifty percent longer, "more detailed in terms of both text and photographs, occasionally blunt in its tone, and full of references to citizenship responsibilities and national military achievements" ( $p$. 20). Many critics suggested that the guide attempted to shape a new image of Canada. The Globe and Mail wrote that the revisions were "a rare and significant attempt to reshape the national image” (p. 20). Similarly, the National Post wrote, “Today's release of a new citizenship guide marks a shift in what it means to become Canadian, emphasizing more than ever the responsibilities bestowed upon the quarter-million newcomers who migrate to Canada each year" (p. 20-21).

The guide was extensively criticized for changing the national image by taking "an incremental step in the rebranding of Canada into a conservative country, full of people more inclined to vote Conservative" ( p. 20). However, Adam Chapnick states that while the latest version of the guide differs in many ways to the immediate former version produced under the Liberal government, he ultimately argues that this guide shares paralleling features to documents produced by other Liberal governments (such as Pierre Trudeau's government). Nevertheless, in an attempt to argue that the guide has not drastically changed over the years to be more ideologically Conservative, Chapnick fails to adequately problematize the 'Canadian values' presented in any of these guides (regardless of political party affiliations associated with the production of the guides) and he does not significantly assess the possible impact these study guides have on Canadian national identity. Moreover, the power structures and relations behind 
who can define national values is not thoroughly considered. Thus, a discourse analysis of the current guide is still warranted.

In addition, Yasmeen Abu-Laban explores how Canadian history and symbolism in the guide places emphasis on more singular, militaristic and patriotic histories instead of social or multicultural histories. Abu-Laban asserts that the Minister of Immigration and Multiculturalism "presented this guide as aimed not only at new immigrants studying for the citizenship test but at the national memory of all Canadians...it seems to be militarized patriotism, and pride in Canada's colonial ties to Britain, that underline the Conservative government's construction of the national memory of a 'good Canadian citizen,' whether that citizen is born in Canada or abroad" (Abu-Laban, 2014, p. 216). To dismantle the Harper government's construction of a national history and identity in the guide — which is a singular historical narrative centered on valorized whiteness - Abu-Laban suggests a more pluralistic and inclusive vision of history. The Harper government has actively taken steps towards influencing how history is constructed in Canada and in the imagination of Canadians. Taking pride in Canada's colonial ties to Britain without highlighting the oppression that also resulted from and benefited such ties, does a great disservice to Canadians (Abu-Laban, 2014). A singular national history that focuses heavily on valorized whiteness and colonial ties excludes particular groups of people (such as Aboriginals or the experiences of immigrants themselves) from Canada's national narrative, ultimately excluding them from a sense of belonging in Canadian society as well.

In addition, Harald Bauder claims that immigration law is one of the few ways nations continue to assert sovereignty during a time where a state's influence is slowly being eroded. As Bauder suggests, while states may have less and less control over the movement of goods, services, capital and information, the state does however, have immense control and power when 
it comes to regulating the movement of people across borders and regulating their membership to the nation through citizenship. Bauder writes, "the nation state possessed the right to include and exclude new members in the national community based on criteria that reflect the collective identity of the national community. In other words, a national community admits new members based on the envisioned identity of this community" (Bauder, 2011, p.6) The term 'envisioned' here is crucial; Harper's government has envisioned core Canadian values, history, and citizenship centered on whiteness that will permeate into the national imagination. Immigrants are often positioned in relation to this 'imagined' Canadian identity as well, and can consequently be excluded from it (Nagendran, 2017).

Furthermore, Stuart Hall asserts that rather than thinking of identity as "an already accomplished historical fact" (Hall, 1989, p.68), identity should be viewed as a "'production' which is never complete, always in process, and always constituted within, not outside, representation" (p.68). This view also destabilizes and undermines the authority or authenticity of 'cultural identity' (Hall, 1989). He suggests that 'cultural identity' can be viewed as "one, shared culture, a sort of collective 'one true self', hiding inside the many other, more superficial or artificially imposed 'selves', which people with a shared history and ancestry hold in common" (Hall, 1989, p. 69) Based on this view, cultural identities in turn "reflect the common historical experiences and shared cultural codes which provide us, as 'one people', with stable, unchanging and continuous frames of reference and meaning, beneath the shifting divisions and vicissitudes of our actual history" (p.69). Thus, representation has historically been, and remains a powerful tool of inclusion and exclusion in shaping national identity. As such, considering what is represented in Discover Canada, and consequently what is omitted from it should be critically examined. 
In examining representation, Lyle Dick interrogates the construction of Canadian historical narratives by examining the House of Commons Heritage Committee's decision to review history in Canada. He examines representation "in federal programs devoted to Canadian history" (Dick, 2014, p. 203) and asserts that it is important to pay attention to political bodies that attempt to make government sponsored or more direct steps towards revising or influencing history. Moreover, it is significant to note that the histories of marginalized groups such as "women, working people, Aboriginal peoples, immigrant communities" (p. 203) and LGBTQ groups often illustrate that these communities view history differently from nationalists (who are interested in advocating a particular history that functions to create a sense of patriotism and national unity. Dick argues that when political bodies interfere in the construction of history, the voices of others (not belonging to dominant groups) are silenced. Ultimately, Dick writes that it is essential to "protect history from political interference" (p. 205) and in doing so, promote the inclusion of diverse histories in our national history.

Based on Abu-Laban's and Dick's exploration of government bodies influencing history, it becomes apparent that history is story-telling—where dominant narratives are a product of construction - prone to omissions and reductions. There is a need to engage and more importantly, interrogate Canada's national history from multiple vantage points in order to capture a multifaceted understanding of the social conditions and inequalities that are sustained by upholding such narratives and how they impact the construction of national identity (Nagendran, 2015). Thus, further examination of the Harper government's influence on policy, national history and the Discover Canada citizenship study guide is needed. 


\section{Chapter 1: Changes and Restrictions Made by Harper's Conservative Government Related to Access to Citizenship}

\section{Citizenship and the Significance of Naturalization}

For many living in Canada, one's national identity can be greatly influenced by their legal status in it. For some, 'acquisition of nationality' can occur automatically (usually at birth). For others, they may engage in a process of 'naturalization'. Naturalization is "generally understood as the non-automatic acquisition of citizenship by an individual who was not a citizen of that country when he or she was born. It requires an application by the immigrant and an act of granting by the host country" (Liebig and Von Haaren, 2011, p. 25). Naturalization, or acquiring formal citizenship status allows immigrants to share a similar status to native-born Canadians, at least legally and politically. Generally speaking, once naturalized, immigrants have the right to vote, they have security from deportation, access to certain jobs, and access to a Canadian passport. Through these rights and benefits, citizenship is situated as a "social category that stratifies the immigrant population and serves as an indicator of immigrant inclusion as well as a measure of social reproduction of the nation through immigration" (Aptekar, 2016). However, it must be stressed here that, naturalization or citizenship alone does not ensure social inclusion for all immigrants equally (Nagendran, 2017).

Furthermore, Elke Winter suggests that naturalization can function as a form of national 'self-flattery' to its people, as well as to the nation's moral character and history. For this to be the case, it is necessary for naturalization to be asked for, desired, and there also needs to be the possibility of rejection. However, those who are characterized as merely taking on a country's citizenship without engaging in a process of 'paying homage' to the people or the nation pose a challenge to maintaining that nation's values and identity. On this point, Winter writes, “they undermine the nation's self-esteem and amour-propre, they undermine the basis of state 
sovereignty and democratic governance, and they undermine the government of the day's claim of being 'in control"' (Winter, 2014, p.5). The government in turn, has a perceived responsibility to maintain a national character that preserves the quality of their national culture, values and institutions (Winter, 2014). This act of national preservation is demonstrated in the ways in which citizenship is used as a tool of both inclusion and exclusion, thereby reinforcing state power and sovereignty (Nagendran, 2017).

\section{Restrictions Made to Access of Citizenship}

Moreover, between 2006 to 2013, Citizenship and Immigration Canada (CIC) under Stephen Harper's government, made changes to citizenship procedures and the naturalization process. For instance, to ground the significance of changes made to the study guide, we can examine how it has already begun to affect newcomers who are applying for their citizenship test. For instance, on March 15, 2010, a new citizenship test corresponding with the content from Discover Canada came into effect. The score required to pass this test rose from 60 percent to 75 percent. In addition to the existing fact-based questions on the citizenship exam, new 'conceptual questions were added (Winter, 2014). The exam also had more emphasis on the rights and responsibilities of citizens compared to prior citizenship tests, while also placing importance on Canada's history, identity and values. Despite the test placing an emphasis on 'Canadian values,' it is important to note here that the guidebook does not explicitly define what 'Canadian values' are. Consequently, increasing failure rates came along with these changes to the citizenship test and the media quickly reported on the issue; the failure rate had risen from between 4 and 8 percent for the old test, to a failure rate of approximately 30 percent for the newest version of the test. CIC was then compelled to modify the test and they later introduced an updated version in October 2010, which reduced the failure rate to 20 percent (Winter, 2014). 
Despite this however, citizenship tests had still become more difficult overall and this had a significant impact on specific applicants. For instance, the new tests indicated a better success rate for candidates from Western countries (with a success rate of over 80 percent), while those from countries such as the Dominican Republic, Somalia, Afghanistan, and Vietnam (to name a few) had significantly lower success rates (which were below 60 percent) (Winter, 2014). Not surprisingly, the test also posed a challenge for those with lower levels of education. These changes also suggest a class or education-based bias which in turn, may have ethno-racial implications (Winter 2014). With these changes to the citizenship test and additional language requirements needed from applicants, large segments of the population (such as lower-class, lesseducated, or refugees) seeking citizenship status may be greatly disadvantaged. Through these changes, the government thereby makes one prove he or she is worthy of citizenship in Canada; this is closely tied to notions of 'deservingness' that positions immigrants as outsiders until they are selected by the state to take advantage of the privileges citizenship affords them (Nagendran, 2017).

\section{Ramifications of Citizenship Changes for Newcomers}

These changes to the citizenship test, which make acquiring citizenship more difficult for some segments of the population, also reflect the government's desire to 'add value' to Canadian citizenship. In addition to making the citizenship test more demanding, creating a new citizenship guidebook, and requiring new language requirements, the Conservative government also established initiatives against the fraudulent acquisition of citizenship (Winter, 2014).

Moreover, candidates who would obtain citizenship during their ceremony were also required to have their face uncovered. In 2011, Minister for Immigration and Multiculturalism, Jason Kenney had heard about citizens who had their faces covered while attending citizenship 
ceremonies as they swore their allegiance to Canada. Shortly after, in December 2011, citizenship certificates were to be given only if new citizens swore allegiance with their faces uncovered. While this change was not explicitly directed at any one group, the implications and overwhelming group it would likely impact were Muslim women who chose to wear the niqab or burqa (Winter, 2014). Kenney insisted that the intention behind this policy was to allow citizenship judges to ensure that new citizens were actually reciting the oath. Kenney believed that their allegiance to the country needed to be clearly seen and understood; he also felt "that covering one's face during the oath of allegiance 'is contrary to Canada's commitment to openness and social cohesion"' (p. 11, citing Kenney, 2011). Kenney is seemingly unaware of the irony in his statement about 'openness' as a Canadian commitment; if Kenney truly was committed to 'being open,' he would understand freedom of religion and belief as fundamental to so-called 'Canadian values' (according to the Canadian Charter of Rights and Freedoms) (Nagendran, 2017).

Ultimately, the government claimed that these changes were intended to "enhance the value and meaning of Canadian citizenship by strengthening civic memory, civic participation and sense of belonging to Canada" (Winter, 2014, p. 21 as cited in Citizenship and Immigration Canada, 2010). This was a part of a Citizenship Action Plan, introduced by Citizenship and Immigration Canada (CIC) in 2009-2010, which included integrated initiatives that would work "to strengthen the integrity of the Citizenship Program" (p. 21). However, Elke Winter suggests that as a result of these changes, specific religions and cultures are singled out and individuals are positioned as unable to adhere to social cohesion (Winter, 2014); this singling out of specific groups is also a feature found in the Discover Canada citizenship study guide (Nagendran, 2017). 


\section{Chapter 2: Analysis and Discussion of Discover Canada Guide}

\section{a) National History and Identity in Discover Canada \\ Political Revisions and Reductions of History}

While Discover Canada attempts to be inclusive by including a segment on 'Aboriginal Peoples' in its 'Who we Are' section, it ultimately falls short by glossing over Canada's 'less appealing' features of history. Instead, it provides a romanticized vision of history that also fails to recognize persisting social inequalities Indigenous communities face that stem from systemic racism and Canada's deeply rooted colonial history. In a line that precedes the section 'Aboriginal Peoples,' the guide states, "To understand what it means to be Canadian, it is important to know about our three founding peoples - Aboriginal, French and British" (Discover Canada, 2012, p. 10). While the acknowledgement of Aboriginal peoples as a founding peoples is significant and commendable, the reductionist portrayal of Canada's history that follows, diminishes this merit. For instance, the guidebook states, "[Aboriginals] were well established here long before explorers from Europe first came to North America" (p.10). However, significant details of European contact with Aboriginals is subject to erasure here. For instance, no mention is made about the violence or conflict that occurred after 'first contact' that devastated Aboriginal communities. Furthermore, the guide follows this with the following paragraph:

Aboriginal and treaty rights are in the Canadian Constitution. Territorial rights were first guaranteed through the Royal Proclamation of 1763 by King George III, and established the basis for negotiating treaties with the newcomers - treaties that were not always fully respected. (Discover Canada, 2012, p.10)

This section ends vaguely — almost cryptically — when describing the routine violation of treaties, which was a consequence of colonization that led to the dispossession of land and the 
dehumanization of Indigenous peoples. This oversimplified statement that merely states "treaties were not always fully respected" does a great disservice to Indigenous communities in Canada today who still live with the consequences of dispossession, displacement and cultural genocide. In fact, the section on "Aboriginal Peoples" later states, "Today about half of the First Nations people live on reserve land in about 600 communities while the other half live off-reserve, mainly in urban centres" (p.10). Again, no explicit attempts are made here to mention the government's role in systematically colonizing lands which created the circumstances that pushed Indigenous communities onto reserves.

Although Discover Canada refers to government enforced residential schools, this section also has troubling reductions and omissions. The guidebook states:

From the 1800s until the 1980s, the federal government placed many Aboriginal children in residential schools to educate and assimilate them into mainstream Canadian culture. The schools were poorly funded and inflicted hardship on the students; some were physically abused. In 2008, Ottawa formally apologized to the former students. In today's Canada, Aboriginal peoples enjoy renewed pride and confidence, and have made significant achievements in agriculture, the environment, business and the arts. (Discover Canada, 2012, p. 10)

This section seems to suggest that residential schools were merely a relic of the past, and that relations between the state and Aboriginal peoples has somehow drastically improved with a formal apology by the government. Canada's 'dark' history of residential schools is reduced to a three-sentence blurb that ends off with a romanticized and neatly wrapped up story-tale like ending, where "In today's Canada, Aboriginal peoples enjoy renewed pride and confidence" (p.10). While recognizing the achievements of Aboriginal peoples is important, not acknowledging the long-lasting impacts that colonization has had and continues to have on Aboriginal communities today is a neglectful omission. 
While the re-telling of history in any context is almost always prone to omissions and reductions, it is still important to call attention to when political bodies attempt to revise or cherry-pick aspects of history to paint more appealing national image of itself (Dick, 2014). Especially in the contexts of this guidebook, which is directed to newcomers preparing for citizenship, the Conservative government's attempt here to remove itself from its past discriminatory policies is concerning. This section showcases the Harper government's efforts to manipulate historical narratives of nationhood, and in doing so has marginalized "dissenting voices in order to unify the country around a simple[r] story" (Eisenberg, 2014, p. 233).

\section{Constructing Partisan National Mythologies}

As Avigail Eisenberg points out, changes made to Canada's symbolic identity—which are reflected in Discover Canada through its emphasis on militaristic events and its pride in Canada’s constitutional monarchy_- "portray Canada nostalgically, simplified and united around images and events that speak more clearly to the roles of men than women, and to the roles of the dominant white settlers and explorers rather than the struggles of Indigenous people or ethnocultural minority immigrants" (Eisenberg, 2014, p. 231). Similarly, Palmer asserts:

Through the manipulation of representations, choices about what to commemorate and what to sidestep, and decisions defying and denying the contest and conflict that have occupied the ground of actual social relations, [the state] 'make[s]' official quite particular readings of the past. (Palmer, 2014, p.234).

The Harper government's project of rewriting history has been carefully crafted to present a more appealing Canadian history that works to placate dominant white nationalist interests that support this reconstruction (Palmer, 2014) and which lends itself to a kind of 'historical amnesia' (Ladner and McCrossan, 2014). For Palmer, "This state project of imagining the nation and its history is, of course, prefabricated and packaged in ways that antagonize academics (and many others) who rightly reject the simplifications, shortcuts, and stubborn sterility of much that is 
presented in the name of national heritage" (Palmer, 2014, p. 234). Thus, it is important to disrupt these constructions of history and bring to the forefront of discussion, the motivations and forethought behind revisionist historical projects such as Discover Canada.

The state involving itself in re-shaping Canada is not unique to Harper's Conservative government. In fact, the state has always played a role in molding history, regardless of political party affiliations. However, what distinguishes Harper from other political leaders is that with him calling the shots, the political imagination of the state "has gone into ideological overdrive" (Palmer, 2014, p. 234). In fact, Discover Canada is not the only area where the Harper government has attempted to revise and manipulate the production of history in Canada. The Harper government has had its hand in many institutions that deal with history production. For example, significant cuts were made to Parks Canada and Library and Archives Canada (which are important institutions that keep factual records of Canada's history), as well as in the creation of new plans for the Museum of Canadian History (Abu-Laban, 2014; Kealey, 2014). During the same time as these federal cuts were being made to institutions that study Canadian history more critically, the Conservative government instead spent twenty-eight million dollars for celebrations related to the War of 1812 (Abu-Laban, 2014; Finkel, 2014; Kealey, 2014). The inclusion of the section on the War of 1812 in Discover Canada received harsh criticism as well when it was first released. A similar type of valorization of the War of 1812 is seen in the guidebook, which paints a glorified account of the events while also minimizing the significant role First Nations and Metis warriors had in the conflict.

Furthermore, Gregory S. Kealey writes that the Harper government is "creating a celebratory myth of a Canadian past that never existed. The propaganda machine is being cranked up...[and] the Harperites want to impose via celebration a simple, unified, patriotic story 
of Canada's past and then pretend it merits the name history" (Kealey, 2014, p. 213). Moreover, the former Minister of Immigration Jason Kenney stressed that "unless we do a better job of teaching history and common values, we risk social unrest in the future" (Kealey, 2014, p. 214). Kenney's words reveal the motivations behind the Conservative government's historical interventions where shared national history—or 'mythologies' rather—are used as tools to promote propagandistic national ideologies (Kealey, 2014). Thus, instead of acknowledging Canada's history of cultural genocide, Indigenous territorial dispossession, as well as past racist and exclusionary immigration policies, Harper's government turns in favour of a history that represents Canada more as a British settler society that has paved the way for Canada to be what it is today (Ladner and McCrossan, 2014).

\section{Ramifications of Representation for Immigrants, Racialized Individuals and Other Minority Groups}

These politically produced national mythologies which center on whiteness and which often take pride in British settler foundations consequently push the voices and stories of immigrants, racialized individuals and other minority groups (such as LGBTQ groups) to the margins of national imagination. In a similar tone used to describe residential schools, the following section titled, "A Railway from Sea to Sea," in Discover Canada covers the construction of the Canadian Pacific Railway.

British Columbia joined Canada in 1871 after Ottawa promised to build a railway to the West Coast. On November 7, 1885, a powerful symbol of unity was completed when Donald Smith (Lord Strathcona), the Scottish-born director of the Canadian Pacific Railway (CPR), drove the last spike. The project was financed by British and American investors and built by both European and Chinese labour. Afterwards the Chinese were subject to discrimination, including the Head Tax, a race-based entry fee. The Government of Canada apologized in 2006 for this discriminatory policy. After many years of heroic work, the CPR's "ribbons of steel" fulfilled a national dream. (Discover Canada, 2012, p. 10) 
Similarly, discriminatory practices here, are framed as an isolated event which has been resolved by a formal government apology. This section also showcases an example of where the hardships and racism experienced by Chinese Canadians is minimized and whitewashed. For instance, the poor working and living conditions experienced by many Chinese labourers who built the CPR (and many of who died as a result of these conditions) is subject to erasure here. Similarly, the Head Tax and its significant impact on separating families is also left out of this revisionist narrative. Instead the exploitation of racialized minorities in building the CPR and the exclusionary immigration policies of the Head Tax are diminished in favour of emphasizing the achievement and 'fulfillment of a national dream.' The apology mentioned in this section points to a trend that many other liberal-democratic-nation-states have joined, in which apologies are made for "historically distant, carefully circumscribed instances of so-called misguided state action, often rhetorically mitigated via references to the antiquated 'attitudes' of past eras" (Henderson \& Wakeham, 2009, p. 2). These apologies often come with no acknowledgement of the ongoing structures of oppression that laid the foundation for 'past' mistakes. Thus, without an understanding of how history informs the 'present,' official government apologies for the atrocities of the past merely pose as highly visible and symbolic public gestures of reconciliation that do not actually lead to significant paradigm shifts that promote healing, reform or social justice. Instead, a false sense of closure is established — not for the effected minority groups, but rather-for the government, which ultimately allows the state to sidestep its responsibility in facilitating further reform and reconciliation (Henderson \& Wakeham, 2009).

Likewise, in describing Japanese internment during the Second World War, the guidebook characteristically sugar-coats the historical event, ending off with yet another reference to a formal government apology; Discover Canada states: 
Regrettably, the state of war and public opinion in B.C. led to the forcible relocation of Canadians of Japanese origin by the federal government and the sale of their property without compensation. This occurred even though the military and the RCMP told Ottawa that they posed little danger to Canada. The Government of Canada apologized in 1988 for wartime wrongs and compensated the victims. (Discover Canada, 2012, p. 23)

This trend of diminishing 'darker aspects' of Canadian history in place of more proud descriptions of militaristic defeat and colonial achievements in an ongoing pattern throughout the guidebook. Other major Canadian events that highlight the experiences of racialized individuals are either not mentioned at all or are referenced very briefly in the guidebook. For instance, no mention is made of the events of Komagata Maru. The Komagatu Maru sailed into Vancouver in 1914, where the 376 South Asian passengers (most of whom were Sikhs) were denied entry by the Canadian government and consequently turned away after the ship had sat in the harbour for two months (Husser, 2016). The turning away of Jewish refugees on the St. Louis is only briefly mentioned in a line that states, "Immigration dropped and many refugees were turned away, including Jews trying to flee Nazi Germany in 1939” (p.22). These few examples alone showcase an alarming trend of diminishing and condensing historic events that either focus upon racialized and minority groups or that create an unfavourable impression upon Canada.

\section{b) Racism-Infused Moral Panic in Discover Canada}

\section{Moral Panic and Racism Related to Immigrants' Cultural Practices}

Moreover, when examining Discover Canada further for sections related to racialized or minority groups - such as comparing the two sections titled, "The Equality of Women and Men in Canada" and "Diversity in Canada" - an underlying sense of moral panic and xenophobia emerges in the guidebook. The section "Diversity in Canada" discusses Canada's pride in its immigrant population, stating: 
The majority of Canadians were born in this country and this has been true since the 1800s. However, Canada is often referred to as a land of immigrants because, over the past 200 years, millions of newcomers have helped to build and defend our way of life. Many ethnic and religious groups live and work in peace as proud Canadians. (Discover Canada, 2012, p.12)

After giving an overview of the different major ethnic groups and religious groups within Canada, the final sentence of the section goes on to state, "Together, these diverse groups, sharing a common Canadian identity, make up today's multicultural society" (p.13). This section paints a pleasant picture of Canada and its relationship with newcomers and immigrants. Unity among Canadian citizens and newcomers is emphasized and the concept of an 'imagined community' that seems to include immigrants and newcomers is stressed here.

Conversely, in a section titled "The Equality of Women and Men in Canada," the passage implies that perhaps relations between Canada and its immigrant population are not as rosy as they appear in the previous section; this section states:

In Canada, men and women are equal under the law. Canada's openness and generosity do not extend to barbaric cultural practices that tolerate spousal abuse, "honour killings," female genital mutilation, forced marriage or other gender-based violence. Those guilty of these crimes are severely punished under Canada's criminal laws. (Discover Canada, 2009, p. 9)

This passage stands in stark contrast to the section on "Diversity in Canada" that precedes it. Despite more attention being given to other sections (such as for historical events, like the war of 1812), the Discover Canada guide makes noteworthy omissions here when discussing gender equality in Canada. It reduces the issue to this three-sentence blurb which focuses upon violence against women and criminality that is linked to cultural practices. However, is this what gender equality in Canada really entails? While this section 'neutral' in wording (as it does not specify what population it directly applies to), its focus on forced marriage, female genital mutilation and polygamy "combined with its tone of Western superiority targets specific groups of immigrants 
assumed to be engaging in these activities" (Gaucher, 2016, p. 527). While it is important to recognize violence against women and while we can agree that we should not condone these practices (which are real and affect women in particular cases), it is necessary however, to problematize the way in which this issue is presented and how it might be exaggerated to achieve a particular goal. This goal refers to the Harper government's explicit attempt to cast suspicion towards the Muslim community in Canada and spread messages with xenophobic undertones in an attempt to legitimize the changes Harper made in policies and law (Nagendran, 2016).

One of the legal changes that legitimized this kind of divisive rhetoric includes when Harper's Conservative government proposed Bill S-7, the Zero Tolerance for Barbaric Cultural Practices Act which passed in 2015 by a vote of 182 to 84 . This act "would raise the marriage age to 16 in addition to adding forced marriage to the Criminal Code. It would also toughen the laws around polygamy, with an eye to preventing immigration by those who engage in the practice and making it easier to deport people who do. And, it would toughen the rules around so-called honour killings" (Csanady, 2015). The discourse that surrounded the Zero Tolerance for Barbaric Cultural Practices Act significantly resembles the language used in "The Equality of Women and Men in Canada" section of the guidebook (Nagendran, 2016).

Despite polygamy already being illegal in Canada, this new legislation appears to not affect the Mormon Bountiful polygamists (Fisk, 2015). The Bountiful polygamists, who are a predominantly white community residing in British Columbia, have been practicing polygamy for nearly fifty years without any significant legal intervention. However, a sudden concern of Muslim immigrants entering Canada and in turn 'importing' their familial and cultural practices (Gaucher, 2016) has led to widespread anxieties, moral panic and xenophobic attitudes about the 'foreign Other' and their culture (Nagendran, 2016). In fact, in a short section titled, "Becoming 
Canadian," (which is featured on the same page as the "Diversity in Canada" section) the Discover Canada study guide explicitly states the following:

Some Canadians immigrate from places where they have experienced warfare or conflict. Such experiences do not justify bringing to Canada violent, extreme or hateful prejudices. In becoming Canadian, newcomers are expected to embrace democratic principles such as the rule of law. (Discover Canada, 2012, p. 12)

This section casts suspicion and fuels existing anxieties about immigrants or newcomers and their ability to 'adapt' or integrate in Canada. Based on these anxieties and attitudes, restrictive policy or legal measures that specifically target immigrant groups are consequently justified. In fact, this became the case when Bill S-7 was passed; the Conservative government used the notion of protecting women from harm as the rationale behind pushing forward bans "on ‘foreign' cultural practices deemed anti-Canadian" (Gaucher, 2016, p. 528).

Furthermore, when the Zero Tolerance for Barbaric Cultural Practices Act passed in 2015, the act also involved an amendment to the Immigration and Refugee Protection Act (IRPA). The change to the IRPA states, "A permanent resident or a foreign national is inadmissible on grounds of practising polygamy if they are or will be practising polygamy with a person who is or will be physically present in Canada at the same time as the permanent resident or foreign national" (Gaucher, 2016, p. 526). Even without a Criminal Code conviction or finding of misrepresentation, immigration officers would be able to deport non-citizens who are suspected of practising polygamy. Moreover, they could also "refuse family reunification to those sponsored spouses believed to be in a polygamous arrangement" (p. 526).

It is interesting to note that this legislation does not come from the Minister of Justice, but instead the Canadian Minister of Citizenship and Immigration (Fisk, 2015). On this issue, the Minister of Citizenship and Immigration at the time, Chris Alexander stated, "Our stance is clear: women and girls in Canada deserve the full protection of the Canadian law. When people try to 
bring these barbaric cultural practices here, our Conservative government has one response: that is not our Canada" (Gaucher, 2016, p. 527). Here, Alexander is making explicit attempts to rationalize this new legislation using the notion of protecting women and girls from harm (Nagendran, 2016). Similar to the rhetoric found in the Discover Canada study guide, Alexander also suggests that that these cultural practices that harm women and girls are 'brought' here by immigrants. This is exacerbated further by his divisive statement, "that is not our Canada," which caters to Canadian white nationalism and fuels existing divides that position Muslims as outsiders (Nagendran, 2016). On this point, Megan Gaucher writes:

This conflation of culture and barbarism reinforces whiteness, as white Canadians are framed as a cultureless population while immigrants of colour engage in culturally problematic behaviour...The language of the act is therefore hypocritical, as it glosses over the complexities of polygamous living in Canada by targeting specific 'barbaric' cultures accused of practices that counter Canadian values and refusing them citizenship. (Gaucher, 2016, p. 529-530)

While the Bountiful polygamists are not necessarily fully condoned in Canada, discussions of this group rarely describe their activities using colonial rhetoric, such as the use of the term 'barbaric cultural practices.' Despite Bountiful polygamists practicing polygamy in Canada for decades, political figures and the Discover Canada study guide still attempt to frame polygamy as if it is a 'new' imported practice. Moreover, framing racialized immigrants as carriers of 'backwards' cultures has real consequences for individuals when considering Bill S-7 and the accompanying changes made to the Immigration and Refugee Protection Act. Consequently, immigrants suspected of engaging in these practices can face significant legal ramifications such as deportation or lack of access to citizenship. The underlying xenophobia present within the "Equality of Women and Men in Canada" section followed by the subsequent passing of Bill S-7 highlights how political rhetoric can have real and legal ramifications for particular groups (Nagendran, 2016). It also seems to suggest that these changes are a coordinated effort by the 
Conservative government to first fuel existing anxieties through political rhetoric, which are than followed my increasingly restrictive policy changes that reflect these attitudes. Here, under the guise of protecting women, Harper's Conservative government uses this issue as a tool to further their political agenda (Nagendran, 2016).

\section{Imperial and Essentializing Modes of Thinking}

Moreover, the colonial language that refers to cultural practices as 'barbaric,' positions Canada (and by extension the West) as superior and more progressive than the 'foreign' cultures that supposedly practice these activities. This imperial way of positioning Canada in relation to other nations is incredibly problematic. Uma Narayan's concept of the 'Package Picture of Cultures' describes this essentialist way of thinking about cultures which paints a generalized picture of what a specific culture is and what it entails; she writes, "This view understands cultures on the model of neatly wrapped packages, sealed off from each other, possessing sharply defined edges or contours, and having distinctive contents that differ from those of other 'cultural packages"' (Narayan, 2000, p. 1084). She says the contents of these 'packages' are not as clear cut as they seem. Instead, political agendas often determine who and what are included inside or outside a 'cultural package' (Narayan, 2000). However, it must be asserted that there is no tidy little box that contains 'authentic,' "monolithic cultural values” (Shakir 2010). Thus, conceptualizing a cultural package is a product of construction (often dictated by elites in power) that is also prone to omissions and reductions. Both Bill S-7 and the Discover Canada guide essentialize immigrants' culture. The barbaric cultural practices belonging to immigrants are seen as 'sealed off' and distinct from Canadian culture. Yet, the hypocrisy of Bill S-7 and the study guide does not acknowledge existing practices of polygamist activities being carried out by white bodies in British Columbia (Nagendran, 2016). This leads to culturally specific 
generalizations being made that make distinctions between 'Western culture,' and 'non-western culture' or 'Canadian women' and 'Muslim women.' These essentialist generalizations homogenize complex and diverse groups and does not take into account the varying nuances of culture that impact people's way of life, political ties, and value systems (Narayan, 2000). Thus, as Sedef Arat-Koc suggests, "The theoretical challenge at this juncture is to see the migrant as a historied subject and in her connectedness to her history, family, and home country, while avoiding essentialist conceptualizations of these forms of connectedness" (Arat-Koc, 2006, p. 85). This is admittedly, a difficult balance to strike.

However, as Narayan also points out, essentialism also functions in a similarly problematic way when discussing Western culture. She argues that the self-portrait of Western culture that is constructed does not accurately represent the political and cultural values that actually exist in Western societies (Narayan, 2000). For instance, in the past, values of liberty and equality were routinely upheld as fundamental to Western values while Western nations were simultaneously "engaged in slavery, colonization, and the denial of liberty and equality to large segments of Western subjects, including women" (p. 1083). Similarly, this constructed selfportrait is the same mechanism that allows Canada to uphold ideas of 'Canadian values' and equality where women are assumed to be protected from harm and treated fairly, all while engaged in ignoring the countless cases of murdered and Indigenous women, despite public appeals for action (Nagendran, 2016). Likewise, the ideology of multiculturalism has become an aspect of Canada's self-portrait, which paints itself proudly as a 'tolerant' and 'inclusive society,' all while engaged in contradictory rhetoric or activities that target minority groups.

Moreover, simplifications and overgeneralizations that emerge from essentialism and a lack of understanding of Muslim communities allows for the maintenance of stereotypes that 
sustain perceptions of difference and 'Otherness' (Nagendran, 2016). In "Recognizing

Strangers," Sara Ahmed asserts that when racist attitudes, stemming from a colonial history, are held towards a particular group, racialized bodies are consequently marked by difference. Difference disallows 'Othered' individuals, whose bodies can be read as markers of belonging, from a sense of inclusion to particular spaces (such as a nation) or an imagined community (Ahmed, 2000). This often results in estrangement and hostility towards Othered individuals who have been systematically oppressed and marginalized. In today's post-9/11 context, the Muslim body is already viewed with hostility and suspicion. In light of this discussion, the Muslim body is consequently also a carrier of culture that threatens 'white Canadian values'. Similarly, focusing on women, Leti Volpp writes:

Women, home, family, and nation become conflated so that women serve to signify a community's culture and tradition. As a result, perceptions of the relative treatment of women have historically been used to assess the progress of a culture and to justify subjugation of different populations in the name of a racialized gender uplift. (Volpp, 2000, p. 108)

The Muslim woman's body than becomes a site of multiple discourses in relation to an 'imagined' Canadian identity. She is someone who needs to be protected from 'violent Muslim men' and Muslim culture, all while still harboring threatening transnational ties herself that deem her cultural ideologies as paradoxical to Canadian values. Through this framework, a perception is constructed in which a Muslim woman needs to be 'saved' from herself (as she is seen as an extension of her culture) and from Muslim men. Consequently, the 'saving force' is positioned as the Canadian government, through Bill S-7 (Nagendran, 2016).

\section{Positioning and Defining 'the West'}

Additionally, gender equality for instance, and how Canada defines itself as 'Canadian' is often measured in relation to other 'underdeveloped nations'; consequently, defining itself in 
relation to 'Other' nations allows Canada to develop a 'superior' national consciousness or identity where the nation has 'progressed' more than other countries on women's issues (Nagendran, 2016). On this point, Volpp writes:

Cultures that are thought to lag behind are often differentiated from the hegemonic culture by race. When people of color are assumed to "lag" because they are governed by cultural dictates, their cultural values stand in stark contrast to reason, supposedly a characteristic of the West...[This is rooted in] Colonialism [which] associated tradition with colonized peoples, ancient ritual, despotism, and barbarity, while connecting modernity to Western progress, democracy, and enlightenment. (Volpp, 2000, p. 96-98)

Ultimately, this imperial mentality conceals or distracts Canadians from the existing inequalities women face here. The rhetoric in the Discover Canada study guide and surrounding discussions around Bill S-7 suggests that gender-based violence is unique to only non-Canadians (Gaucher 532) which ultimately denies the presence of similar societal issues already present in Canada.

As already stated, Canada has high rates of missing and murdered Indigenous women, and yet Stephen Harper's Conservative government has routinely neglected to address the issue despite appeals from human rights organizations to do so (Nagendran, 2016). His selectivity when it comes to which women and girls deserve protection from harm and from what forms of harm is highlighted in how he deals with violence against Indigenous women and that perceived to be violence perpetrated by Muslim men against Muslim women. This selectivity ultimately highlights the inauthenticity of his government's claims to provide women and girls full protection of the law, when law officials (the Royal Canadian Mounted Police) ignore the issue of murdered and missing indigenous women. According to a report released by the InterAmerican Commission on Human Rights, "the police have failed to adequately prevent and protect indigenous women and girls from killings and disappearances, extreme forms of violence, and have failed to diligently and promptly investigate these acts" ("Missing and 
Murdered Indigenous Women", 2014, p.12). The conditions in which these murders and disappearances occur have a direct relation to Canada's deeply rooted colonial and patriarchal history with ramifications that continue to persist today; this in turn, creates the culture or circumstances in which these murders and disappearances of Indigenous peoples takes place (Nagendran, 2016). In addition, domestic violence and sexual violence in the workplace still remain commonplace in Canada (Gaucher, 2016). Equitable pay for women, lack of childcare services, political representation and a whole host of other issues significantly affect women in Canada today.

Therefore, in light of the many real inequities women and girls face in Canada, the section on "Equality of Women and Men in Canada" serves as tool to distract Canadians from Canada's own culturally specific problems. As Gaucher writes:

In using specific cultural groups as scapegoats, the government is sidestepping the issue of gender-based violence within Canadian borders, denying victims of any agency or resources to improve their situation. While the government claims that the primary motivator behind the act is the avoidance of harm, it presents consequences for the same parties it claims to protect... it is worth asking whether protection from harm is truly the goal of this particular piece of legislation. (Gaucher, 2016. p. 533)

Claiming to protect women from harm, while simultaneously not providing the services and tools women actually need to access help to leave violent circumstances, highlights the inauthentic claims of the government and indicates ulterior political motivations.

\section{The Conditions of Belonging}

This emerging contradiction (between the "Diversity in Canada" section and the "The Equality of Women and Men in Canada" section) makes clear the conditionality that comes with living in a self-identified multicultural state. For instance, writing for the positionality of a 'visible minority' living in Canada, Bannerji states: 
There is a fundamental unease with how our difference is constructed and constructed by the state, how our otherness in relation to Canada is projected and objectified. We cannot be successfully ingested, or assimilated, or made to vanish from where we are not wanted. We remain an ambiguous presence, our existence a question mark in the side of the nation, with the potential to disclose much about the political unconsciousness and consciousness of Canada as an iimagined community'... We have the awareness that we have arrived into somebody's state, but what kind of state; whose imagined community or community of imagination does it embody? And what are the terms and conditions of our 'belonging' to this state of nation? (Bannerji, 2008, p. 105-106)

As Bannerji suggests, simply residing in a nation that claims to uphold the dogma of multiculturalism does very little to actually foster a sense of belonging. Ultimately, the spread of discourse that aims to create suspicion and foster simplified assumptions towards immigrants and visible minorities does a great disservice to those who are seeking meaningful inclusion in a society that claims to be multicultural. Instead, a nation-state that simultaneously spreads multicultural rhetoric while casting suspicion and fear against those viewed as outsiders is routinely being reinforced. One would think that these two contradicting ideologies seem to be on the verge of rupture, and yet despite this tension, these discourses have continued to be maintained over time (especially since the events of 9/11). It can be argued that this is largely due to the immense power that political bodies and leaders hold that affords them the ability to legitimize even the most inconsistent or conflicting ideologies. Thus, the imagined community of Canada can attempt to exclude its own citizens for instance, all while patting itself on its back for having a diverse population that it reluctantly tolerates.

\section{Real-life Consequences Stemming from Discourse}

Hence, the way in which government officials, such as Jason Kenney or Chris Alexander (former Ministers of Immigration), who speak publicly about other groups' culture must be critically assessed. Their rhetoric holds power by virtue of their formal position in government which gives value to their words and ultimately legitimizes it. In today’s post 9/11 context, 
where securitization and national sovereignty are becoming increasingly significant, Muslim bodies and identities are routinely essentialized in both discourse and representation. Overtime, this discourse and the accompanying representations of this group are embedded within the very fabric of Canadian society; citizens soon learn to interpret and register difference, leading them to view specific individuals as Others in their daily life (Nagendran, 2016). On this note, in "The Spectacle of the "Other," Stuart Hall writes:

Representation is a complex business and, especially when dealing with 'difference', it engages feelings, attitudes and emotions and it mobilizes fears and anxieties in the viewer, at deeper level than we can explain in a simple, common-sense way. This is why we need theories - to deepen our analysis. (Hall, 1997, p. 226)

In accordance with Hall, there is a need to deepen our analysis and problematize the way in which the Discover Canada citizenship study guide frames cultural practices that incites negative perceptions of immigrants. The discourse that often surrounds Muslim culture and the way in which language is employed creates and maintains already existing divides between Muslims and the rest of Canada (Nagendran, 2016). Their perceived cultural values by dominant groups in Canadian society are often positioned as paradoxical or threatening to so-called 'Canadian Values.' This leads to dangerous notions of who a 'good' or 'ideal' citizen is and who is deserving of citizenship, which often falls along ethno-racial lines (Nagendran, 2017).

This divide between the 'good' and 'threatening' citizen took on an almost literal meaning during the last federal election. The Conservatives vowed to create a RCMP tip line that would allow Canadians to report instances where a child or woman were engaged in barbaric cultural practices (Maloney, 2015). This proposal was announced by the Status of Women Minster, who at the time was Kellie Leitch. During a period when national debates were taking place about women wearing the niqab during their citizenship ceremonies, Leitch had said, "These practices have no place in Canadian society...By contrast, Justin Trudeau and Thomas 
Mulcair are more worried about political correctness than tackling these difficult issues that impact women" (Maloney, 2015). In contrast to Leitch, Cameron Ahmad, a liberal spokesman stated that this proposal highlights the Conservatives' campaign strategy which focuses on fostering "fear and division" (Maloney, 2015). He had also remarked, "A tip line to report crime already exists: it's 9-1-1" (Maloney, 2015). In light of this proposal coming during the federal election, the Conservative government methodically ignited and fuelled anxieties as a campaign strategy. This tip line was not to prevent women from becoming victims of 'barbaric' practices, but as Ahmad suggested to create divisions among Canadians. Moreover, the tip line proposal sent a clear message to the Canadian public that if elected, the Conservative government would be tough and punish those engaged in these practices (Nagendran, 2016). If this tip line had been established, it would have essentially allowed supposed 'good' citizens to act as policing agents against those who they perceived as engaged in practices threatening 'Canadian values' (Nagendran, 2017).

Furthermore, Canadian values are often framed in a way where certain cultural differences are perceived to be paradoxical to Canadian values and mutually exclusive. For instance, the Ontario Conservative MP, Kellie Leitch, has recently proposed that immigration and refugee applicants be screened for 'anti-Canadian values.' She proposed the idea in a campaign questionnaire that was sent to potential supporters (Smith, 2016). This was met with mixed reactions as Leitch had formerly stated that she regretted her involvement in promoting the proposal to establish a tip line for 'barbaric cultural practices' during the last federal election (Smith, 2016). Her rhetoric in defending the anti-Canadian values test aligns closely with the Discover Canada guide and Bill S-7; Leitch stated:

This is about protecting Canadian values and people that believe that women are property, that they can be beaten and bought or sold, or believe that gays or lesbians 
should be stoned because of who they love, don't share in my opinion, basic Canadian values... This isn't about disagreement, but about acceptance of a framework by which we agree to live as Canadians and the tolerance that goes with that, because here in this country, we are tolerant. (Smith, 2016)

Racialized minorities and immigrants often are required by the state to ideologically prove that they belong to the nation; this in turn is often tied to issues of Canadian citizenship and 'deservingness.' As Wendy Brown suggests, “Tolerance is generally conferred by those who do not require it on those who do; it arises within and codifies a normative order in which those who deviate from rather than conform to the norms are eligible for tolerance" (Brown, 2006, p.186). In other words, those who belong to the hegemonic dominant group are able to tolerate, while the racialized or foreign 'Other' is the one who is 'tolerated.' This process of tolerating reinforces and strengthens existing power relations that disadvantages racialized minorities and immigrants within the context of a multicultural state

Thus, by examining these sections from Discover Canada and by attempting to contextualize them both socially and historically, one finds that the guidebook is incredibly problematic in its representation. This discussion thus far has attempted to disrupt these constructions by taking an anti-racist and post-colonial perspective. Ultimately, the hope is that future guidebooks take into account the varied and rich histories of Indigenous groups, racialized groups, and other minority groups that better reflect Canadian society. 


\section{Chapter 3: Future Guidebooks}

Through this examination of the Discover Canada citizenship study guide, it is also important to discuss an alternative to how future guidebooks can frame information pertaining to Canada and Canadian citizenship in a way that does not fall into some of the dangerous traps discussed in this paper. It is important for future guidebooks to not deny or romanticize Canadian history and existing conditions in Canada. While there is merit to Discover Canada having sections that acknowledge Indigenous peoples and sections that outline specific instances of progress made by Canada, these sections ultimately fall short. It is problematic when no effort is made to acknowledge the racism and 'cleansing' of Indigeneity in the Residential Schools' atrocities or to not mention the work that still needs to be done in Canada, such as areas related to Indigenous rights, women's rights, LGBTQ+ rights and the rights of marginalized and racialized communities. An acknowledgement of existing inequities would work against romanticizing existing conditions that stem from a colonial and racist history in Canada.

Recently, former Liberal Immigration Minister John McCallum had announced early in 2016 that Discover Canada was up for revision, and while revisions have been ongoing for the past year, there is no confirmed date as to when the new guidebook will be released. The conception of this guidebook differs drastically from other publications, as briefing notes show that almost every government department is being consulted for their input, with Prime Minister Trudeau himself sharing his remarks on what themes should be covered. The Canadian Press has obtained a draft of the upcoming citizenship study guidebook which makes significant revisions that aim to remove some of the more troubling aspects of Discover Canada, such as the increased emphasis placed on the War of 1812 and its reference to cultural barbaric practices (Levitz, 2017). According to The Toronto Star, the working copy of the new citizenship 
guidebook does in fact remove references to barbaric cultural practices, as well as taking out a line which states getting a job as one of the responsibilities of citizenship. The new guidebook instead, separates the responsibilities of citizenship into criteria that is voluntary and mandatory. For instance, voluntary responsibilities include respecting the human rights of others, understanding official bilingualism and participating in the political process, while mandatory responsibilities include obeying the law, serving on a jury, paying taxes, filling out the census and respecting treaties with Indigenous People (Levitz, 2017). For instance, the working copy of the new guidebook states, "Today, Canadians, for example, can own their own homes and buy land thanks to treaties that the government negotiated...Every Canadian has responsibilities under those treaties as well. They are agreements of honour" (Levitz, 2017).

A noteworthy addition in the working copy of the guide is a more extensive emphasis "into the history and present-day lives of Indigenous Peoples, including multiple references to the Truth and Reconciliation Commission's report on residential schools and a lengthy section on what happened at those schools" (Levitz, 2017). In comparison to the single paragraph that discusses residential schools in Discover Canada, this is a welcomed revision. Moreover, unlike previous guidebooks, the working draft also has significant sections that cover Canadian history pertaining to discrimination faced by Chinese, South Asians, Jews and disabled Canadians. The new guidebook also delves deeper into documenting the fight for LGBTQ rights. In fact, some bureaucrats had wanted to include similar themes about LGBTQ issues and rights in Discover Canada, but former Immigration Minister Jason Kenney overruled it, resulting in very limited references to such issues, such as one line about gay marriage (Levitz, 2017). The Toronto Star reports that, "The rewrite is part of a much broader renewal of citizenship laws and process that 
is underway. In June, legislation passed that changed the age for those who need to pass the knowledge test for citizenship, among other things" (Levitz, 2017).

While it is a good step forward for the current government to acknowledge the problematic features of Discover Canada, it would be remiss to not also acknowledge the impact that the former Harper government's ideologies had on policy and how it has left behind lingering anxieties around issues of white nationalism, racism and xenophobia. Thus, the critical examination of Discover Canada and the troublesome aspects of it that were brought to the forefront of this discussion does not become irrelevant simply because a new guidebook is being produced. In fact, it acts to signal to current decision makers the difficulty in constructing 'Canadian values' and responsibilities, without falling into similar traps of romanticizing history and existing conditions for minority communities in Canada. 


\section{Conclusion}

More recently, with the election of President Donald Trump in the U.S., racism, xenophobia and white nationalism are more explicitly seen. With similar sentiments continuing to gain traction in Canada, the ideas highlighted in this MRP become incredibly salient. Thus, when we consider Canada's continued promotion of multiculturalism, one must recognize that the ideology does very little to actually foster the social inclusion of racialized and minority groups in society. Instead, upholding multiculturalism functions to obscure inequalities that stem from Canada's colonial and racist history. As Jane Ku writes, "multiculturalism is a hegemonic and normative strategy and, sometimes, an assumed reality in which we are all equal...Multiculturalist discourse has successfully asserted the act of naming blatant racism alone (without touching the underlying causes) as effectively dealing with racism" (Ku, 2008, p. $52-53)$.

Thus, multiculturalism on an ideological level functions in a similar way to how government apologies for past historical atrocities has often allowed the state to experience a false sense of accomplishment and thereby evade its responsibility of further facilitating the social integration of diverse groups. To truly promote multiculturalism in Canada, purposeful and thoughtful action must also be taken by the government to facilitate significant paradigm shifts that result in real change. However, something that often impedes these paradigm shifts is the government's continued denial or reluctance to interrogate Canada's foundation of colonialism. As bell hooks asserts:

[I]t becomes evident that part of our contemporary crisis is created by a lack of meaningful access to truth... When this collective cultural consumption of and attachment to misinformation is coupled with layers of lying individuals...our capacity to face reality is severely diminished as is our will to intervene and change unjust circumstances. (hooks, 1994, p. 29) 
Thus, when it comes to politicians like Stephen Harper, Donald Trump or even Justin Trudeau, it is necessary to continually interrogate their political rhetoric critically, and to also then challenge the problematic discourse on which their statements and actions are based.

If we are to move forward then, it is imperative that the Canadian government and its political leaders experience "a reckoning with the overarching and ongoing structures of colonialism" (Henderson \& Wakeham, 2009, p. 13). There is a need to collectively "reject a naïve progressivist model of history that 'views this past and its violence as, in fact, past, and so, no longer pertinent to a present practice of justice"” (Henderson \& Wakeham, 2009, p. 13 as cited in Baucom, 2005, p. 305). With this understanding, there is also a need to bring more varied histories to the forefront of national discourse; this includes counter histories and histories of resistance that work against white nationalist agendas.

However, as we are currently seeing in recent events taking place in the U.S, there is often hostile opposition from white nationalists and white supremacists who perceive even the most marginal shifts away from white centered ideologies as direct threats to their existence and 'superiority.' As such, bell hooks states, "how deep-seated is the fear that any de-centering of Western civilizations, of the white canon is really an act of cultural genocide. Some folks think that everyone who supports cultural diversity wants to replace one dictatorship of knowing with another...This is perhaps the gravest misconception of cultural diversity" (hooks, 1994, p. 32). Yet in spite of this backlash from white nationalist groups, we have a responsibility to bring forth new modes of thinking to the forefront of public discourse; in doing so, we can help shape a society where multiple knowledges and histories can simultaneously coexist without being mutually exclusive. Thus, historians, political scientists, sociologists, other academics and the public must push back and continue to challenge white nationalist rhetoric (Palmer, 2014, p. 
237). Admittedly, this task does not always come easy, but as bell hooks poignantly asserts, we must endure through "the protracted nature of our struggle and be willing to remain both patient and vigilant...in [our] collective dedication to truth" (hooks, 1994, p. 33)! 


\section{Bibliography}

Abu-Laban, Y. (2014). The Politics of History Under Harper. Labour, 73, 215-17.

Ahmed, S.(2000). Recognising Strangers. Strange Encounters: Embodied Others in Postcoloniality. London and New York: Routledge, 21-37.

Alexander, J. C. (2013). Struggling Over the Mode of Incorporation: Backlash Against Multiculturalism in Europe. Ethnic and Racial Studies, 36(4), 531-556.

Ali, M. A. (2017). Weaving the Tapestry: From description to analysis and interpretation. Lecture presented in Ryerson University, Toronto.

Anderson, B. (1983). Imagined Communities: Reflections on the Origin and Spread of Nationalism. London: Verso.

Aptekar, S. (2015). Making Sense of Naturalization: What Citizenship Means to Naturalizing Immigrants in Canada and the USA. Journal of International Migration and Integration, 17(4), 1143-1161.

Arat-Koc, S. (2006). Whose Social Reproduction? Transnational Motherhood and Challenges to Feminist Political Economy. Social Reproduction: Feminist Political Economy Challenges Neoliberalism. McGill Queen's UP, 75-92.

Barriers to Citizenship for Newcomers to Canada. (2014). Canadian Council for Refugees. Retrieved April 09, 2017 from http://ccrweb.ca/en/barriers-citizenship.

Bauder, H. (2011). Immigration Dialectic: Imagining Community, Economy, and Nation. Toronto: University of Toronto Press.

Berger, R. (2015). Now I see it, now I don't: researcher's position and reflexivity in qualitative research. Qualitative Research, 15(2), 219-234.

Berry, W. J. (2013). Research on Multiculturalism in Canada. International Journal of Intercultural Relations, 37 (6), 663-75.

Brady, M. J. (2013). Media Practices and Painful Pasts: The Public Testimonial in Canada's Truth and Reconciliation Commission. Media International Australia, Incorporating Cultures \& Policy, (149), 128-138).

Brown, W. (2006). Regulating Aversion: Tolerance in the Age of Identity and Empire. NJ: Princeton UP.

Calhoun, C. (1993). Nationalism and Ethnicity. Annual Review of Sociology, 19(1), 211-239. 
Chapnick, A. (2011). A 'Conservative' National Story? The Evolution of Citizenship and Immigration Canada's Discover Canada. American Review of Canadian Studies, 41(1), 20-36.

Csanady, A. (2015). Barbaric Cultural Practices' Bill to Criminalize Forced Marriage, Tackle 'Honour Killings' Passes Final Vote. National Post. Retrieved April 08, 2017, from http://news.nationalpost.com/news/canada/canadian-politics/barbaric-cultural-practicesbill-to-criminalize-forced-marriage-tackle-honour-killings-set-for-final-vote.

Dick, L. (2014). Remarks on the Harper Government's Review of History. Labour (Halifax), 73, 203-05.

Discover Canada: The Rights and Responsibilities of Citizenship Study Guide. (2009). Minister of Public Works and Government Services Canada, Citizenship and Immigration Canada. Retrieved April 9, 2017 from http://www.cic.gc.ca/english/pdf/pub/discover.pdf.

Eisenberg, A. (2014). Identity Politics: Conservative Style. Labour/Le Travail, (73),231-233.

Fekete, L. (2004). Anti-Muslim Racism and the European Security State. Race \& Class, 46(1), 3 29).

Finkel, A. (2014). Harper's Vision of the Future Requires Reshaping of the Past. Labour, (73), 197-199.

Fisk, R. (2015). If Stephen Harper is Serious About Criminalizing Barbaric Cultural Practices Then He Should Arrest Himself for Even Suggesting It. Independent. Retrieved April 8, 2017 from http://www.independent.co.uk/voices/comment/if-stephen-harper-is-seriousabout-criminalising-barbaric-cultural-practices-then-he-should-arrest-himself-for-evensuggesting-it-10126055.html.

Frost, C. (2011). How Canada Killed Multiculturalism. Canadian Ethnic Studies, 43(1-2), 253264.

Full Text of Peter Mansbridge's Interview with Stephen Harper. (2014). CBC News. Retrieved June 06, 2017 from http://www.cbc.ca/news/politics/full-text-of-peter-mansbridge-sinterview-with-stephen-harper-1.2876934.

Gaucher, M. (2016). Monogamous Canadian Citizenship, Constructing Foreignness and the Limits of Harm Discourse. Canadian Journal of Political Science, 49(03), 519-38.

Government of Canada. (2015). Discover Canada. Retrieved April 16, 2017, from http://www.cic.gc.ca/english/resources/publications/discover/. 
Guibernau, M. (2007). National Identity, Devolution and Secession. The Identity of Nations, Cambridge: Polity Press, 33-57.

Gündüz, Z. Y. (2010). The European Union at 50-Xenophobia, Islamophobia and the Rise of the Radical Right. Journal of Muslim Minority Affairs, 30(1), 35-47.

Hall, S. (1997). The Spectacle of the "Other." Representation: Cultural Representations and Signifying Practices. London: Sage, 225-77.

Hall, S. (1989). Cultural Identity and Cinematic Representation. Framework, 0(36), 68-82.

Hardy, C., Harley, B., \& Phillips, N. (2004). Discourse Analysis and Content Analysis: Two Solitudes? Qualitative Methods, 19-22.

Harper, S. (2008). Statement of Apology to Former Students of Indian Residential Schools. Government of Canada: Indigenous and Northern Affairs Canada . Retreived April 07, 2017 from https://www.aadnc-aandc.gc.ca/eng/1100100015644/1100100015649.

Henderson, J., \& Wakeham, P. (2009). Colonial Reckoning, National Reconciliation?: Aboriginal Peoples and the Culture of Redress in Canada. ESC: English Studies in Canada, 35(1), 1-26).

Herrera, M. Y., \& Braumoeller, F. B. (2004). Symposium: Discourse and Content Analysis. Qualitative Methods, 15-19.

Hewitt, R. (2005). White backlash and the politics of multiculturalism. Cambridge: Cambridge University Press.

hooks, b.(1994). A Revolution of Values: The Promise of Multicultural Change. Teaching to Transgress: Education as the Practice of Freedom. New York: Routledge. 23-24.

Husser, A. (2016). Komagato Maru Apology: Ship's story represents 'dark chapter' of Canada's past. CBC News. Retrieved August 20, 2017, from http://www.cbc.ca/news/canada/komagata-maru-backgrounder-apology-1.3584372.

Kealey, G. S. (2014). Harper and non-history. Labour, (73), 213-214.

Kendall, G. \& Wickham G. (1999). 'My head is spinning; doesn't history have to be more orderly than this?'. Introducing Qualitative Methods: Using Foucault's Methods, 21-56.

$\mathrm{Ku}$, J. (2008). Irrational Subjects and Hallucinations of Peace and Order. Crash Politics and Antiracism: Interrogations of Liberal Race Discourse. New York: Peter Lang, 49-69. 
Ladner, K. L., \& McCrossan, M. (2014). Whose share history? Labour, (73), 200-202.

Levitz, S. (2017). New Citizenship study guide highlights Indigenous Peoples, Canadian responsibilities. Retrieved July 28, 2017 from https://www.thestar.com/news/canada/2017/07/23/new-citizenship-study-guidehighlights-indigenous-peoples-canadian-responsibilities.html

Liebig, T., and F. Von Haaren. (2011). Citizenship and the Socio-economic Integration of Immigrants and Their Children: An Overview across European Union and OECD Countries. Naturalisation: A Passport for the Better Integration of Immigrants?, OECD Publishing, 24-65.

Maloney, R. (2015). Tories Pledge Tip Line for 'Barbaric Cultural Practices. The Huffington Post. Retrieved April 08, 2017 from http://www.huffingtonpost.ca/2015/10/02/tip-linebarbaric-cultural-practices-tories_n_8234610.html.

Makaryk, I. R. (1993). Encyclopedia of Contemporary Literary Theory: Approaches, Scholars, Terms. University of Toronto Press.

Millard, G. (2009). Stephen Harper and the Politics of the Bully. The Dalhousie Review, 89(3), 329-336.

Missing and Murdered Indigenous Women in British Columbia, Canada. (2014). Organization of American States: Inter-American Commission On Human Rights, Retrieved July 23, 2017 from http://www.oas.org/en/iachr/reports/pdfs/Indigenous-Women-BC-Canada-en.pdf.

Nagendran, S. (2015). Interrogating Canada's Colonial Past and Systemic Racism: Missing and Murdered Aboriginal Women in Canada. Unpublished Paper, University of Toronto.

Nagendran, S. (2016). Xenophobic 'Canadian Values': Examining the Zero Tolerance for Barbaric Cultural Practices Act. Unpublished Paper, Ryerson University.

Nagendran, S. (2017). Constructing the 'Good' Canadian Citizen: Examining the Discover Canada Citizenship and Immigration Study Guide. Unpublished Paper, Ryerson University.

Narayan, U. (2000). Undoing the 'Package Picture of Culture. Signs: Journal of Women, Culture and Society. 25(4), 1083-1086.

Palmer, B. D. (2014). Imagining Politics. Labour/Le Travail, (73), 234-237. 
Phillips, N. \& Hardy, C. (2002). What is Discourse Analysis? Qualitative Research Methods: Discourse analysis : SAGE Publications Ltd. 1-17.

Poynting, S., \& Mason, V. (2008). The New Integrationism, the State and Islamophobia: Retreat from Multiculturalism in Australia. International Journal of Law, Crime and Justice, 36(4), 230-246.

Schneider, F. (2013). How to Do a Discourse Analysis. Retrieved April 16, 2017, from http://www.politicseastasia.com/studying/how-to-do-a-discourse-analysis/.

Shakir, U. (2010). Aqsa Parvez: A Canadian Tragedy Lost in 'culture Talk.' Rabble.ca. Retrieved July 23, 2017 from http://rabble.ca/blogs/bloggers/uzma-shakir/2010/06/aqsaparvez-canadian-tragedy-lost-culture-talk.

Shields, J., \& Evans, B. (2012). Building a Policy-Oriented Research Partnership for Knowledge Mobilization and Knowledge Transfer: The Case of the Canadian Metropolis Project. Administrative Sciences, 2(4), 250-272.

Smith, J. (2016). Immigration Test Not About Singling Out Muslims: Leitch. The Huffington Post. Retrieved July 24, 2017 from http://www.huffingtonpost.ca/2016/09/07/kellieleitch-immigration-values-test-muslims_n_11887654.html.

Wayland, S. V. (2006). Collaboration and conflict: immigration and settlement-related advocacy in Canada. CERIS: Policy Matters, 26, 1-5.

Wherry, A. (2009). What He Was Talking about When He Talked about Colonialism. Maclean's. Retrieved April 08, 2017 from http://www.macleans.ca/politics/ottawa/what-he-wastalking-about-when-he-talked-about-colonialism/.

White, R. (2004). Discourse Analysis and Social Constructionism. Nurse Researcher, 12(2), 716.

Winter, E. (2017). Rethinking Multiculturalism After Its Retreat: Lessons from Canada. American Behavioral Scientist. 59(6), 637-57.

Winter, E. (2014). Becoming Canadian: Making Sense of Recent Changes to Citizenship Rules. Institute for Research on Public Policy, 44, 1-25.

Volpp, L. (2000). Blaming Culture for Bad Behaviour. Yale Journal of Law and the Humanities, $12,89-116$. 